\title{
Ground Magnetometer Surveys Over Known and Suspected Breccia Pipes on the Coconino Plateau, Northwestern Arizona
}

\section{U.S. GEOLOGICAL SURVEY BULLETIN 1683-C}

This research was funded by the Bureau of Indian Affairs in cooperation with the

Hualapai Indian Tribe

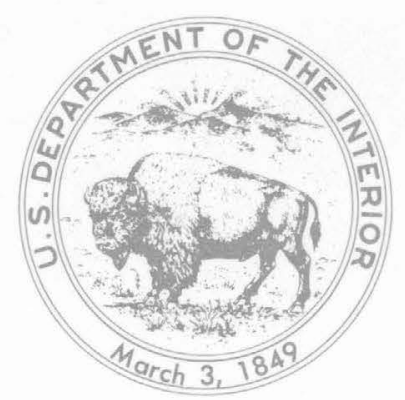




\section{AVAILABILITY OF BOOKS AND MAPS OF THE U.S. GEOLOGICAL SURVEY}

Instructions on ordering publications of the U.S. Geological Survey, along with prices of the last offerings, are given in the current-year issues of the monthly catalog "New Publications of the U.S. Geological Survey." Prices of available U.S. Geological Survey publications released prior to the current year are listed in the most recent annual "Price and Availability List." Publications that are listed in various U.S. Geological Survey catalogs (see back inside cover) but not listed in the most recent annual "Price and Availability List" are no longer available.

Prices of reports released to the open files are given in the listing "U.S. Geological Survey Open-File Reports," updated monthly, which is for sale in microfiche from the U.S. Geological Survey, Books and Open-File Reports Section, Federal Center, Box 25425, Denver, CO 80225. Reports released through the NTIS may be obtained by writing to the National Technical Information Service, U.S. Department of Commerce, Springfield, VA 22161; please include NTIS report number with inquiry.

Order U.S. Geological Survey publications by mail or over the counter from the offices given below.

\section{BY MAIL}

\section{Books}

Professional Papers, Bulletins, Water-Supply Papers, Techniques of Water-Resources Investigations, Circulars, publications of general interest (such as leaflets, pamphlets, booklets), single copies of Earthquakes \& Volcanoes, Preliminary Determination of Epicenters, and some miscellaneous reports, including some of the foregoing series that have gone out of print at the Superintendent of Documents, are obtainable by mail from

\section{U.S. Geological Survey, Books and Open-File Reports Federal Center, Box 25425 Denver, CO 80225}

Subscriptions to periodicals (Earthquakes \& Volcanoes and Preliminary Determination of Epicenters) can be obtained ONLY from the

\section{Superintendent of Documents \\ Government Printing Office \\ Washington, D.C. 20402}

(Check or money order must be payable to Superintendent of Documents.)

\section{Maps}

For maps, address mail orders to

\section{U.S. Geological Survey, Map Distribution \\ Federal Center, Box 25286 \\ Denver, CO 80225}

Residents of Alaska may order maps from

\author{
Alaska Distribution Section, U.S. Geological Survey, \\ New Federal Bullding - Box 12 \\ 101 Twelfth Ave., Falrbanks, AK 99701
}

\section{OVER THE COUNTER}

\section{Books}

Books of the U.S. Geological Survey are available over the counter at the following Geological Survey Public Inquiries Offices, all of which are authorized agents of the Superintendent of Documents:

- WASHINGTON, D.C.--Main Interior Bldg., 2600 corridor, 18 th and C Sts., NW.

- DENVER, Colorado--Federal Bldg., Rm. 169, 1961 Stout St.

- LOS ANGELES, California--Federal Eldg., Rm. 7638, 300 N. Los Angeles St.

- MENLO PARK, California--Bldg. 3 (Stop 533), Rm. 3128 , 345 Middlefield Rd.

- RESTON, Virginia--503 National Center, Rm. 1C402, 12201 Sunrise Valley Dr.

- SALT LAKE CITY, Utah--Federal Bldg., Rm. 8105, 125 South State St.

- SAN FRANCISCO, California--Customhouse, Rm. 504, 555 Battery St.

- SPOKANE, Washington--U.S. Courthouse, Rm. 678, West 920 Riverside Ave..

- ANCHORAGE, Alaska--Rm. 101, 4230 University Dr.

- ANCHORAGE, Alaska--Federal Bldg, Rm. E-146, 701 C St.

\section{Maps}

Maps may be purchased over the counter at the U.S. Geological Survey offices where books are sold (all addresses in above list) and at the following Geological Survey offices:

- ROLLA, Missouri--1400 Independence Rd.

- DENVER, Colorado--Map Distribution, Bldg. 810, Federal Center

- FAIRBANKS, Alaska--New Federal Bldg., 101 Twelfth Ave. 
Chapter C

\section{Ground Magnetometer Surveys Over Known and Suspected Breccia Pipes on the Coconino Plateau, Northwestern Arizona}

BY BRADLEY S. VAN GOSEN and KAREN J. WENRICH

Computer graphics by WILLIAM L. THOEN

This research was funded by the Bureau of Indian Affairs

in cooperation with the

Hualapai Indian Tribe

U.S. GEOLOGICAL SURVEY BULLETIN 1683

BRECCIA PIPES IN NORTHERN ARIZONA 
DEPARTMENT OF THE INTERIOR DONALD PAUL HODEL, Secretary

U.S. GEOLOGICAL SURVEY

Dallas L. Peck, Director

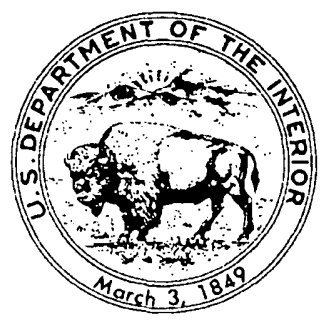

For sale by the Books and Open-File Reports Section

U.S. Geological Survey

Federal Center, Box 25425

Denver, CO 80225

Any use of trade names in this report is for descriptive purposes only and does not imply endorsement by the U.S. Geological Survey.

\section{Library of Congress Cataloging-in-Publication Data}

Van Gosen, B. S. (Bradley S.), 1960-

Ground magnetometer surveys over known and suspected breccia pipes on the Coconino Plateau, northwestern Arizona.

(U.S. Geological Survey bulletin ; 1683-C)

Bibliography: $p$.

1. Breccia-Arizona-Coconino County. 2. Magnetic prospectingArizona-Coconino County.

I. Wenrich, Karen J. II. Title. III. Title: Ground magnetometer surveys over

breccia pipes, Arizona. IV. Series: Geological Survey bulletin ; 1683-C

QE75.B9

[QE471.15.B7]

no. $1683-\mathrm{C} \quad 557.3 \mathrm{~s}, \quad 88-600259$ 


\section{CONTENTS}

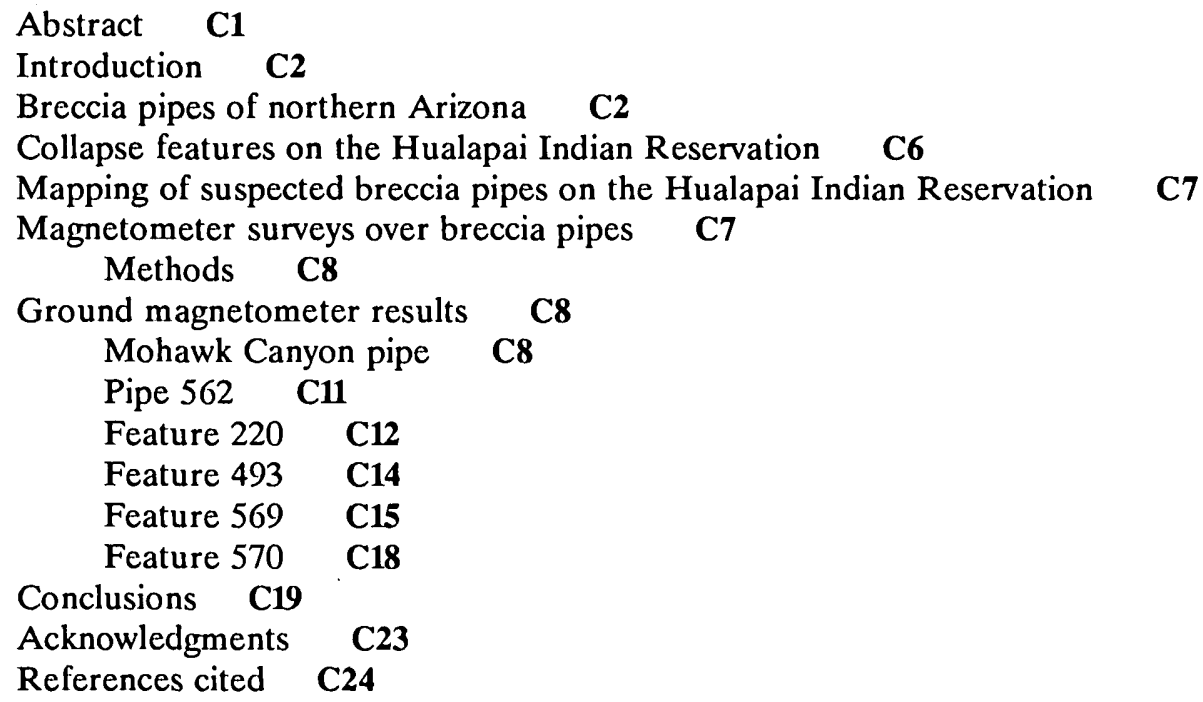

\section{FIGURES}

1. Index map of northern Arizona showing the location of plateaus, Hualapai Indian Reservation, San Francisco volcanic field, and breccia pipes developed into mines $\mathbf{C 3}$

2. Map of Hualapai Indian Reservation showing solution-collapse features C4

3. Schematic cross section of a breccia pipe showing rock units that host breccia pipes in the Grand Canyon region of Arizona C5

4. Map of Hualapai Indian Reservation showing collapse features surveyed by ground magnetometer C9

5. Photograph of the Mohawk Canyon pipe $\mathbf{C 1 0}$

6. Geologic map of the Mohawk Canyon pipe showing location of ground magnetometer readings and drill holes C11

7. Total magnetic field profiles of ground magnetometer traverses at the Mohawk Canyon pipe $\mathbf{C 1 2}$

8. Diagram showing three-dimensional model and contour plot of the ground magnetometer data for the Mohawk Canyon pipe $\mathbf{C 1 3}$

9. Photograph of pipe $562 \quad$ C14

10. Map showing the location of ground magnetometer readings at pipe $562 \quad \mathbf{C 1 5}$

11. Total magnetic field profiles of ground magnetometer traverses at pipe $562 \quad$ C16

12. Diagram showing three-dimensional model and contour plot of the ground magnetometer data for pipe $562 \quad \mathbf{C 1 7}$

13. Photograph of feature $220 \quad$ C18 
14. Map showing location of ground magnetometer readings at feature $220 \quad \mathbf{C 1 9}$

15. Total magnetic field profiles of ground magnetometer traverses at feature $220 \quad$ C19

16. Diagram showing three-dimensional model and contour plot of ground magnetometer data for feature 220

17. Photograph of feature 493 C21

18. Map showing the location of ground magnetometer readings at feature $493 \quad$ C22

19. Total magnetic field profiles of ground magnetometer traverses at feature $493 \quad$ C22

20. Diagram showing three-dimensional model and contour plot of ground magnetometer data for feature $493 \quad \mathbf{C 2 3}$

21. Photograph of feature $569 \quad \mathbf{C 2 4}$

22. Map showing the location of ground magnetometer readings relative to the rim of feature $569 \quad \mathbf{C 2 5}$

23. Total magnetic profiles of ground magnetometer traverses at feature $569 \quad$ C26

24. Diagram showing three-dimensional model and contour plot of ground magnetometer data for feature $569 \quad \mathbf{C 2 7}$

25. Diagram showing computer modeling for the source of the dipole magnetic anomaly recorded along line 2 at feature $569 \quad \mathbf{C 2 8}$

26. Photograph of feature $570 \quad$ C29

27. Map showing location of ground magnetometer readings at feature $570 \quad$ C30

28. Total magnetic field profiles of ground magnetometer traverses at feature $570 \quad$ C30

29. Diagram showing three-dimensional model and contour plot of ground magnetometer data for feature $570 \quad$ C31

TABLE

1. Statistics for the data set of $\mathbf{5 3 1}$ ground magnetometer readings recorded during the study of six breccia pipes 


\title{
Ground Magnetometer Surveys Over Known and Suspected Breccia Pipes on the Coconino Plateau, Northwestern Arizona
}

\author{
By Bradley S. Van Gosen and Karen J. Wenrich
}

Computer graphics by William L. Thoen

\begin{abstract}
The Colorado Plateau in northern Arizona is host to hundreds, possibly thousands, of solution-collapse breccia pipes; many contain concentrated deposits of copper, uranium, silver, lead, zinc, cobalt, and nickel minerals. These breccia pipes, which formed by solution and collapse within the Mississippian Redwall Limestone and by progressive upward stoping of the overlying strata, extend into the Triassic Chinle Formation. The discovery of high-grade uranium ore in some pipes, plus potentially economic concentrations of other byproduct metals, has stimulated mining and exploration throughout northern Arizona in recent years.
\end{abstract}

More than 900 confirmed and suspected breccia pipes were mapped on the Hualapai Reservation from 1982 to 1986. Mapping breccia pipes on the Coconino Plateau (on the eastern half of the reservation) is complicated by relatively recent karst development (sinkholes) on the Kaibab Limestone surface and collapses formed by dissolution of gypsum units within the Permian Kaibab Limestone and Toroweap Formation. Both types of collapse features have little economic value.

Six known or suspected breccia pipes that crop out on the Coconino Plateau were surveyed by a ground magnetometer, which had a sensitivity of \pm 0.02 gammas. The Mohawk Canyon pipe contains surface copper mineralization and subsurface uranium mineralization; a dipole magnetic anomaly was recorded over the pipe, with the low magnetic area positioned N. $70^{\circ} \mathrm{E}$. of the high magnetic area. Exploratory drilling at pipe 562 indicates a uraniummineralized pipe at depth; anomalously low magnetic values occur in the collapsed interior of the pipe. Surveys over

Manuscript approved for publication May 20, 1988. feature 220, which appears to be a stratiform copper deposit (it is uncertain whether this deposit overlies a pipe), reveal an area of anomalously high magnetic values north of the feature and an area of low magnetic values near the excavated pit. Audio-magnetotelluric soundings and field observations at feature 493 suggest it is a breccia pipe that is enclosed by a moat, which was probably formed by Kaibab or Toroweap gypsum collapse; an east-west-oriented dipole magnetic anomaly was recorded at the central hill. The peanut-shaped morphology of feature 569 suggests that it represents the intergrowth of two breccia pipes. Two areas of anomalously high magnetic values and two areas of anomalously low magnetic values were detected within and bordering the collapse of feature 569, again suggesting that two coalescing breccia pipes underlie the collapse. Although audio-magnetotelluric soundings and surface morphology suggest that feature 570 overlies a breccia pipe, the magnetic gradient that was recorded here lacks the anomalies associated with the other collapses that have been surveyed.

A dipole magnetic anomaly recorded along line 2 at feature 569 was modeled to determine the magnetic source. The best-fit model reveals that: (1) The magnetic source begins at the surface and extends to a depth of at least $50 \mathrm{~m}$, (2) the source is slightly smaller than the surface diameter of the collapse, and (3) the magnetic susceptibilities recorded are typical of detrital magnetism in sedimentary rocks.

The dipole magnetic anomalies that were recorded may reflect Triassic Moenkopi Formation downdropped into a less magnetic Kaibab Limestone host rock. In addition, the anomalously low magnetic values recorded, such as over pipe 562 and feature 220, may indicate the alteration of magnetic minerals within the reduced zones that are associated with the uranium ore deposits in mineralized breccia pipes. In this second scenario, replacement of the detrital ilmenite and magnetite within the bleached (reduced) rocks by nonmagnetic iron and titanium minerals, such as 
pyrite and leucoxene, creates a relative magnetic depletion over the pipe.

\section{INTRODUCTION}

The Colorado Plateau in northern Arizona is host to hundreds, probably thousands, of solution-collapse breccia pipes, many of which contain concentrated deposits of $\mathrm{Cu}, \mathrm{U}, \mathrm{Ag}, \mathrm{Pb}, \mathrm{Zn}, \mathrm{Co}$, and Ni minerals. The discovery of high-grade uranium ore in some of these pipes, and its association with potentially economic concentrations of the other byproduct metals, has stimulated mining and exploration for mineralized breccia pipes throughout northern Arizona in recent years. Bowles (1965) was the first to recognize the northern Arizona breccia pipes as solution-collapse features; earlier work had suggested the pipes were volcanic in origin.

The recent interest in mineralized breccia pipes has been carried onto the $1,550-\mathrm{mi}^{2}$ Hualapai Indian Reservation, which is located on the southwestern corner of the Colorado Plateau in northwestern Arizona (fig. 1). More than 900 confirmed and suspected breccia pipes were mapped on the Hualapai Reservation from 1982 to 1986 (fig. 2; also see Wenrich, Billingsley, and Huntoon, 1986, 1987; and Billingsley and others, 1986). Ground magnetometer surveys are one of several exploration techniques that have been used to distinguish potentially mineralized, deeper rooted breccia pipes from nonmineralized, shallow collapses and other circular features. Throughout this paper the terms "solution collapse," "structure," or "feature" are defined as those areas that apparently have undergone collapse due to dissolution of underlying rock, whereas the term "breccia pipe" refers specifically to dissolution of the Redwall Limestone that resulted in stoping and brecciation of the overlying rock.

Note to reader: All measurement units presented in this paper are given in the unit in which the measurement was made during the study; that is, to provide smoother reading the corresponding conversions to feet or meters are not simultaneously provided. Feet may be calculated by multiplying meters by 3.281 ; meters may be calculated by multiplying feet by 0.3048 .

\section{BRECCIA PIPES OF NORTHERN ARIZONA}

Breccia pipes formed as the result of solution and collapse within the Mississippian Redwall Limestone and collapse through progressive upward stoping of the overlying strata. An extensive karst system developed in the Redwall Limestone sometime after its depostion, and caverns that formed became filled with rubble and blocks from the overlying strata. Continued upward stoping of the overlying strata produced a pipelike column of mixed lithologies, usually no more than $300 \mathrm{ft}$ in diameter. The stoping and steep walls of the pipe produced extensive brecciation, which was generally most developed toward the center of the pipe. All breccia dropped downward into the pipe; no breccia clasts have been observed that occur above their normal stratigraphic position. Northern Arizona breccia pipes and the associated mineralized rocks transgress the entire upper Paleozoic section from the Misssissippian Redwall Limestone to the Triassic Chinle Formation of the Mesozoic section (fig. 3). No volcanic rocks are associated in time or space with the formation of the pipes.

A steeply dipping (subvertical), circular stope fracture zone formed in the country rock along the perimeter of each breccia pipe. This fracture zone is commonly mineralized, if the breccia pipe is mineralized, and it separates the breccia body from the relatively undisturbed wall rock. In this paper the stope fracture zone will be referred to as the "ring fracture," which is the term that has been applied by recent workers (Wenrich, 1985).

The breccia pipes of the Colorado Plateau are abundant south of the Utah border to the Mogollon Rim (the southern margin of the plateau), west to the Grand Wash Cliffs (the western margin of the plateau), and east across the Marble Plateau of the Navajo Indian Reservation (fig. 1). No breccia pipes have been found east of the Echo Cliffs. The lavas of the San Francisco volcanic field bury terrane with a high potential for breccia pipes. Recent studies have identified the galliumand germanium-rich Apex Mine in the Beaver Dam Mountains of southwestern Utah as an oxidized Colorado Plateau-type collapse breccia pipe (Wenrich and others, 1987; Verbeek and others, 1987); this breccia body was previously interpreted as fault created (Kinkel, 1951; Bernstein, 1986). This suggests that the Arizona pipes extend into the southern Basin and Range province in those areas underlain by the Redwall Limestone or equivalent units.

The region best known for breccia pipes and most active for recent exploration is the Arizona Strip, which extends from the Grand Canyon northward to the Utah border. Figure 1 shows the location of several mineralized breccia pipes that have been mined within the Arizona Strip, including the three Hack Canyon mines, the Kanab North mine, the Pigeon mine, the Hermit mine, and the Pinenut deposit, all which went into, or are going into, operation during the 1980's.

Recent exploration interest in mineralized breccia pipes of northern Arizona has resulted in numerous multidisciplinary studies, which are summarized and referenced here. 


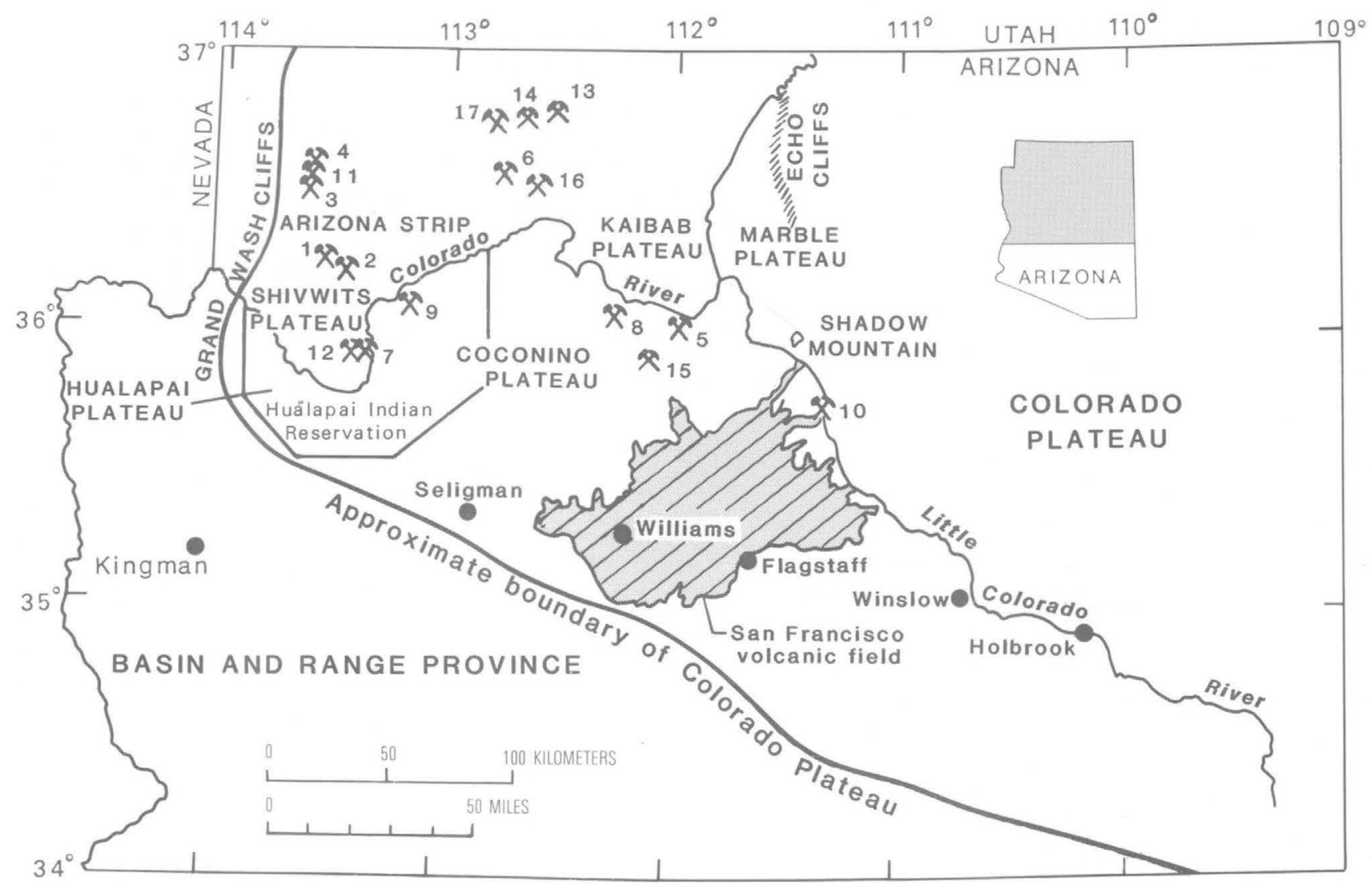

Figure 1. Index map of northern Arizona showing the location of plateaus, Hualapai Indian Reservation, boundary of the Colorado Plateau (Mogollon Rim), the San Francisco volcanic field (its lavas bury terrane with high potential for breccia pipes), and breccia pipes presently or previously developed into mines. Numbers refer to the following mines:

$\begin{array}{llll}1 \text { Copper House } & 6 \text { Hack Canyon } & 11 \text { Savanic } & 16 \text { Pinenut } \\ 2 \text { Copper Mountain } & 7 \text { Old Bonnie } & 12 \text { Snyder } & 17 \text { Hermit } \\ 3 \text { Cunningham } & 8 \text { Orphan } & 13 \text { Pigeon } \\ 4 \text { Grand Gulch } & 9 \text { Ridenour } & 14 \text { Kanab North } \\ 5 \text { Grandview } & 10 \text { Riverview } & 15 \text { Canyon }\end{array}$

An extensive suite of elements are anomalously concentrated and commonly associated with the highgrade uranium ore in mineralized breccia pipes. A thorough discussion of breccia-pipe mineralization and geochemistry is provided in Wenrich (1985), and a discussion of geochemical exploration for mineralized pipes is provided in Wenrich (1986); also, photographs of several breccia pipes are shown in each of these papers. Except for the presence of uranium, many samples from the ore zone in Colorado Plateau pipes are strikingly similar in geochemistry and appearance to Mississippi Valley deposits; this is discussed in Wenrich (1985), Wenrich and others (1988), Wenrich and Pratt (1985), and Wenrich, Billingsley, and Van Gosen (1986). The paragenesis and formation of ore minerals from mineralized pipes are discussed in Wenrich and Pratt (1985). In some pipes a black, pore-filling pyrobitumen is associated with the ore minerals; the results of RockEval analyses of this pyrobitumen are presented in Wenrich and Pratt (1985) and Wenrich (1986). Geochemical analyses of organic material associated with the breccia pipes are discussed by Landais (1986).

Using $\mathrm{U}-\mathrm{Pb}$ isotope analyses, the minimum age of formation for uraninite from the Orphan mine breccia pipe was determined to be $141 \mathrm{Ma}$ (Gornitz and Kerr, 1970). U-Pb isotope measurements on samples from several northern Arizona breccia pipes suggest uranium mineralization occurred 200-220 Ma (Ludwig and others, 1986). The significance of these age determinations is also discussed in Wenrich $(1985,1986)$.

Fluid inclusion studies have been conducted on dolomite, sphalerite, and calcite samples from mineralized pipes. The results show that the temperatures of the transporting fluids were $80-173{ }^{\circ} \mathrm{C}$, with an average salinity of about 20 weight percent $\mathrm{NaCl}$ equivalent. Further discussion of fluid inclusion data is available in Wenrich (1985, 1986), Wenrich and Pratt (1985), and Rasmussen and others (1986). 


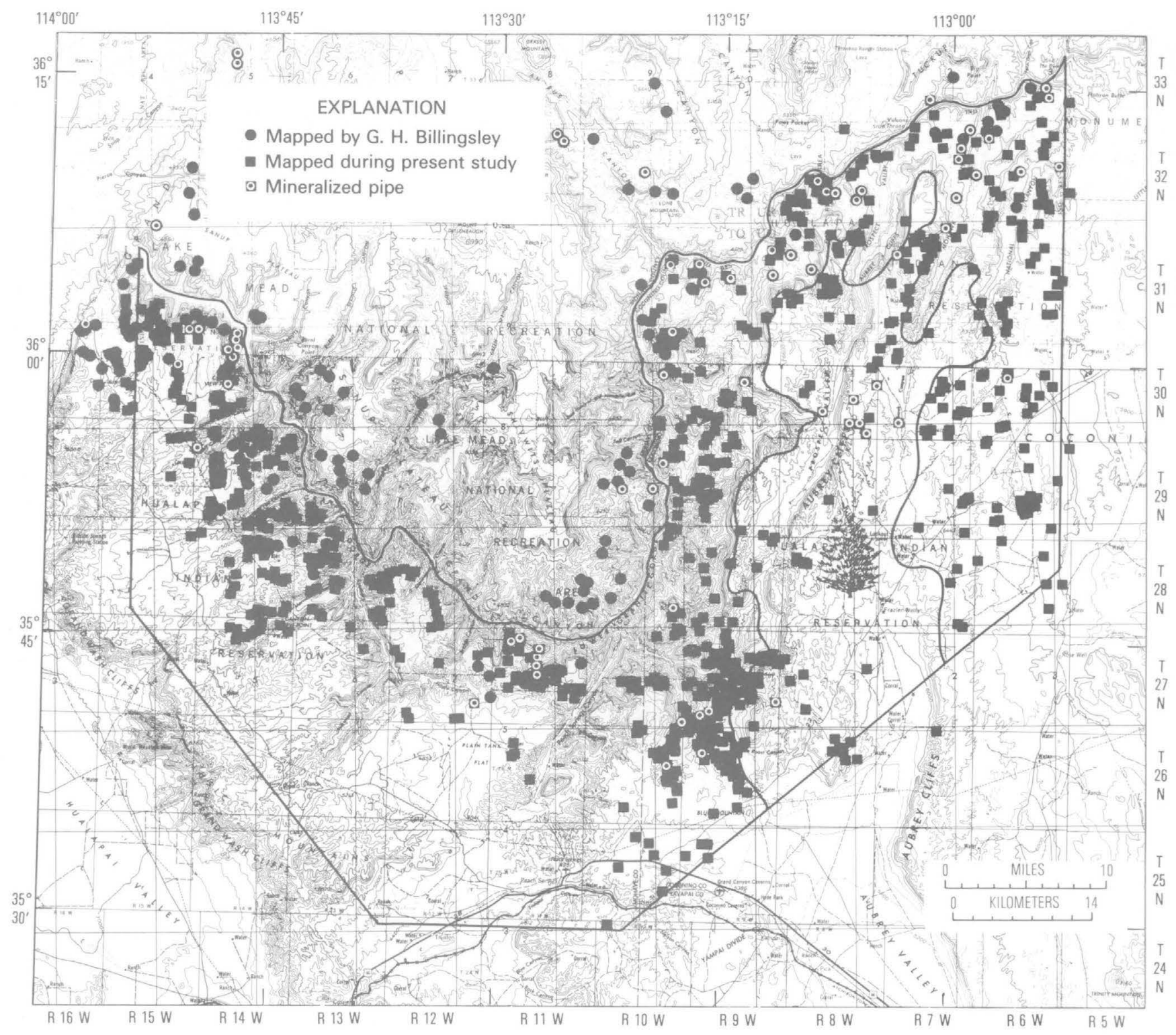

Figure 2. This map of the Hualapai Indian Reservation and vicinity illustrates the density of solution-collapse features existing in northern Arizona. Over 900 confirmed and suspected breccia pipes have been mapped within and adjacent to the Hualapai Reservation. Vegetation is sparse on the western side of the reservation, which is reflected in the greater density of identified collapses. Area outlined in black (with tree symbol in the center) on eastern side of map is densely tree covered, which prevents recognition of most pipes. Future refinement of Landsat imagery may aid exploration for breccia pipes in these forested areas.

Mineralized breccia pipes commonly occur in clusters, which suggests that each pipe in the cluster is connected by a common hydrogeochemical system. The density of pipe locations and possible hydrologic relations are discussed in Wenrich $(1985,1986)$. Huntoon (1986) discussed breccia pipe hydrology and provided good evidence for ascending mineralizing fluids. There is evidence for the structural alignment of pipes, especially on the Marble Plateau, and this is presented in Sutphin (1986) and in Sutphin and Wenrich $(1983,1986)$. This evidence for breccia-pipe alignments on the Marble Plateau was evaluated by Wheeler (1986).
The Surprise Canyon Formation was deposited in the Grand Canyon region during Late Mississippian and possibly Early Pennsylvanian time, sometime after the deposition of the underlying Redwall Limestone and before the deposition of the Supai Group (Billingsley and Beus, 1985). The Surprise Canyon was deposited in stream-eroded valleys and solution caverns within the Redwall Limestone karst surface. The relationship of the Surprise Canyon to the breccia pipes is discussed by Billingsley (1986).

The production figures and mine history of the Orphan mine, a copper- and uranium-mineralized pipe 
Average or range

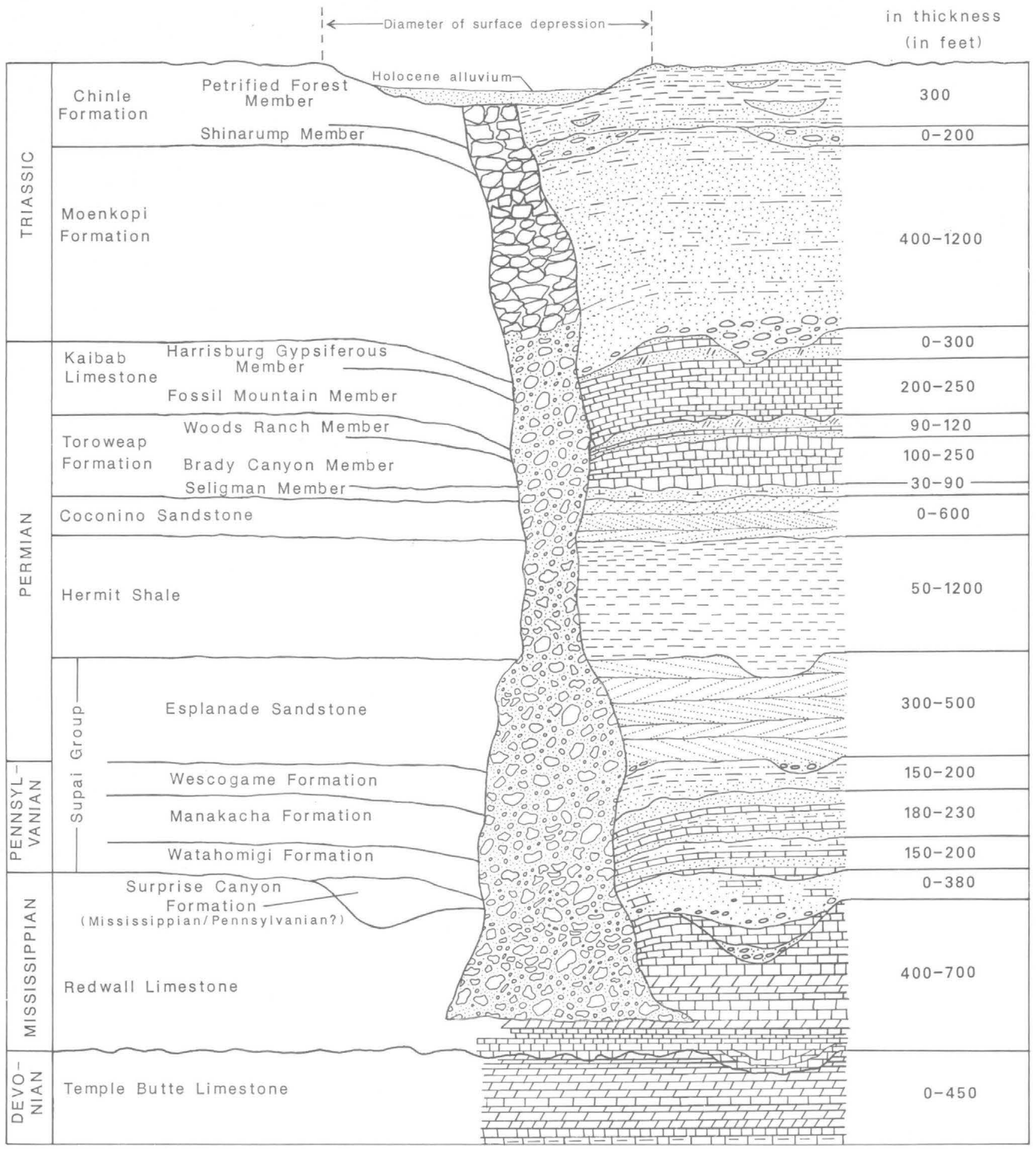

Figure 3. Schematic cross section of a breccia pipe (based on cliff exposures in the Grand Canyon of Arizona). The unit thicknesses shown for the Triassic Chinle and Moenkopi Formations (not present in the study area for this report) represent their thickness ranges in the Grand Canyon area. The unit thicknesses for the lower Paleozoic strata correspond to thicknesses that occur in the Coconino Plateau of the eastern Hualapai Reservation (from Wenrich, Billingsley, and Huntoon,1986, which also provides unit descriptions). Some collapse features on the Coconino Plateau, such as collapse feature 493, have reddish centers which may be the result of downdropped Moenkopi sediments. 
in the Grand Canyon National Park, were presented in detail by Chenoweth (1986). His report provides an example of the "typical" ore reserves for a mineralized Colorado Plateau breccia pipe, plus a historical anthology.

Results of detailed studies of particular mineralized pipes are available for (1) the Orphan mine (Gornitz and Kerr, 1970; Chenoweth, 1986); (2) the EZ-2 pipe (Krewedl and Carisey, 1986); 3) the Riverview mine (Chenoweth and Blakemore, 1961); (4) the Copper House mine (Bromfield, 1952); (5) the Copper Mountain mine (Osterstock and others, 1954); (6) the Copper House, Copper Mountain, and Parashant mines (Watkins, 1975); (7) the Hack Canyon mines (Casebolt and others, 1986); and (8) the Ridenour mine (Miller, 1954; Verbeek and others, 1988).

\section{COLLAPSE FEATURES ON THE HUALAPAI INDIAN RESERVATION}

The Hualapai Indian Reservation is situated on the southwestern corner of the Colorado Plateau (fig. 1), which is bounded on the west by the Grand Wash Cliffs; these cliffs are the western limit of breccia pipes for the Arizona Strip. The western half of the reservation lies on the Hualapai Plateau, which is capped by the Redwall Limestone. On the Hualapai Plateau no more than $500 \mathrm{ft}$ of rock strata is available to host an orebody, and little of it is sandstone. This is a problem because the orebodies that are found in mineralized breccia pipes in northern Arizona consistently occur within breccia composed dominantly of sandstone clasts. Thus, the Hualapai Plateau is considered to have relatively little potential for economically mineralized breccia pipes. The eastern half of the Hualapai Reservation occupies the western edge of the Coconino Plateau, which is capped primarily by the Harrisburg Gypsiferous Member of the Kaibab Limestone (fig. 3). The Coconino Plateau surface is underlain by at least $2,500 \mathrm{ft}$ of strata which includes the sandstone units that commonly host orebodies within breccia pipes along the Arizona Strip. Thus, magnetometer surveys on the Hualapai Reservation were confined to collapse features exposed on the Coconino Plateau surface; specifically, all surveys were conducted on the Harrisburg Gypsiferous Member of the Kaibab Limestone.

A map of the Hualapai Reservation (fig. 2), where more than 900 confirmed and suspected breccia pipes were mapped during 1982-1986, shows the density of collapse features that is typical in northern Arizona. The mapping of breccia pipes on the high plateaus capped by the Kaibab Limestone (such as the Coconino, Kaibab, and Marble Plateaus) is complicated by (1) relatively recent karst development on the Kaibab surface, and (2) formation of collapse features by dissolution of gypsum units in the Harrisburg Gypsiferous Member of the Kaibab Limestone and the Woods Ranch Member of the underlying Toroweap Formation. Collapse features of the first type shall be referred to in this paper as "sinkholes", which are characterized by vertical walls that lack inward-dipping beds and a bottom that contains uncemented rubble; thus, sinkholes appear to be relatively recent karst features. Collapse features of the second type shall be referred to as "gypsum collapses," which on a plateau surface are difficult to distinguish from surface manifestations of the deep-rooted breccia pipes. Both gypsum collapses and sinkholes are considered to have little economic value because they appear to have formed after the regional mineralizing fluid phase that occurred sometime in the Triassic, and they do not extend downward into the sandstone units which most commonly host the orebodies. For this report, "breccia pipes" will refer only to those collapse features that appear to originate in the Redwall Limestone and are formed by the stoping and brecciation of the overlying strata.

In canyons where a cross-sectional view of the third dimension is exposed, it is possible to distinguish gypsum collapses from Redwall breccia pipes. Locally a breccia pipe is exposed along a canyon rim, where a breccia column that crops out on the canyon wall is directly overlain by a circular, shallow, structural basin on the plateau. The surface expression of this structural basin has been enhanced by underlying gypsum dissolution, as fluid percolating through the pipe moved laterally into the gypsiferous units. This effect of increased dissolution adjacent to breccia pipes was observed in drill core from the Mohawk Canyon pipe (Wenrich and others, 1988), where the gypsiferous Woods Ranch Member of the Toroweap Formation was almost entirely removed from the breccia body. Thus, the collapse feature expressed on the plateau surface is generally much larger than the underlying breccia column. The Shadow Mountain collapse feature on the Marble Plateau is the largest (more than $1 \mathrm{mi}$ in diameter) collapse feature known in northern Arizona. However, the known orebodies that occur in mineralized breccia pipes are much smaller, generally $100-400 \mathrm{ft}$ in diameter.

It is important to develop relatively inexpensive geochemical and geophysical exploration techniques, prior to drilling, that will distinguish uneconomic gypsum collapses from potentially economic, deep-seated breccia pipes. Ground magnetometer surveys are one of several exploration techniques that have been tested over suspected and known breccia pipes. Geochemical surveys tested (with mixed results, see Wenrich, 1986) include hydrogeochemical, soil geochemistry, helium soil-gas (Reimer, 1985; Reimer and Been, 1986), Bacillus cereus (bacteria), rock geochemistry, clay hydrocarbon, and 
thermoluminescence sampling surveys. Two geophysical techniques, scaler AMT (audio-magnetotelluric) and E-field telluric, have produced profile data that delineate mineralized breccia pipes from surrounding terrane (Flanigan, Tippens, and others, 1986). After suspected breccia pipes are mapped, geophysical profiles and geochemical surveys provide useful techniques for selecting drilling targets.

\section{MAPPING OF SUSPECTED BRECCIA PIPES ON THE HUALAPAI INDIAN RESERVATION}

The selection of targets for exploration surveys on the Hualapai Reservation began with the mapping of suspected breccia pipes (fig. 2) on 1:24,000-scale color photographs; suspiciously circular features or alteration halos were chosen from the photographs and field checked. Many features were also spotted from a helicopter, especially those pipes exposed in cliff faces that are not visible on the aerial photographs. The mapping of the Hualapai Reservation and vicinity is presented in Wenrich, Billingsley, and Huntoon (1986, 1987) and Billingsley and others (1986).

Exploration criteria for evaluating the potential of each collapse feature were developed during the mapping project. The following criteria are considered favorable indicators for a mineralized breccia pipe:

(1) Concentrically inward dipping beds.

(2) A circular topographic pattern. This is commonly expressed as a topographically high rim around a central depression.

(3) Anomalous radioactivity. A count that is 2.5 times background or higher is considered anomalous.

(4) Goethite pseudomorphs and molds of pyrite.

(5) Colloform celadonite-stained chalcedony.

(6) Copper mineralization. This is expressed on surface exposure as the supergene minerals malachite, azurite, brochantite, and chrysocolla.

(7) Breccia, other than intraformational breccias.

(8) Anomalous concentrations in surface samples of such trace elements as $\mathrm{Ag}, \mathrm{As}, \mathrm{Cd}$, $\mathrm{Co}, \mathrm{Cu}, \mathrm{Mo}, \mathrm{Ni}, \mathrm{Pb}, \mathrm{Se}, \mathrm{V}$, and $\mathrm{Zn}$.

(9) A circular vegetation or color pattern.

These criteria must be evaluated by field checking to verify the presence of a breccia pipe. Few pipes (including those features evaluated in this report) exhibit all nine criteria on surface exposure, but the more criteria that are present, the more potential a suspected pipe is believed to have.

\section{MAGNETOMETER SURVEYS OVER BRECCIA PIPES}

Geophysical prospecting over breccia pipes is dependent on the principle that the pipe itself is physically distinct from the surrounding strata. Conductivity anomalies from AMT and E-field telluric profile data have successfully delineated breccia pipes (Flanigan, Tippens, and others, 1986). Transient or timedomain electromagnetic surveying has shown changes in resistivity between the breccia column and the adjacent country rock (Standish and Schmeling, 1986). Shallow seismic studies across breccia pipes show promise in distinguishing the ring fracture, the inward-dipping beds, and the breccia mass from the surrounding strata (Hasbrouck, 1986).

The sedimentary units that host breccia pipes can be expected to exert low magnetic intensities because of their detrital ilmenite. The uranium ore deposits within Colorado Plateau pipes are not known to contain magnetic minerals such as magnetite, ilmenite, and pyrrhotite. The deposits in these pipes contain such sulfide minerals as pyrite, marcasite, galena, arsenopyrite, millerite, gersdorffite, siegenite, and sphalerite, plus the copper sulfides chalcocite, covellite, chalcopyrite, enargite, tennantite, digenite, and djurleite. The magnetic iron sulfide, pyrrhotite, has not been found within pipe deposits, nor is it expected to be associated with the aforementioned lower temperature mineral assemblage.

A petrographic study of the Moenkopi Formation by R.A. Cadigan (in Stewart and others, 1972) identified detrital magnetite, magnetite-ilemenite, and ilmenite, which "occur as black to brown, rounded to subangular, opaque grains." Preliminary thin section analyses by H.B. Sutphin (oral commun., 1987) indicate that the Moenkopi Formation contains a higher concentration of heavy minerals, including ilmenite and magnetite, than does the underlying Kaibab Limestone, Toroweap Formation, or Coconino Sandstone. Detrital ilmenite, which is more common than magnetite, may locally compose as much as 2 percent of the Moenkopi framework grains. In contrast, clastic horizons from the aforementioned underlying units generally contain only trace amounts, if any, of ilmenite or magnetite, and the carbonate horizons lack these minerals altogether. Thus, blocks of Moenkopi Formation that have been downdropped into a breccia pipe contained within the Kaibab Limestone or Toroweap Formation can be expected to exhibit a magnetic anomaly relative to the surrounding country rock. 
Modeling of magnetic anomalies can be used to estimate the depth of the anomaly. A best-fit magnetic model for the breccia pipe can be used to calculate an anomaly depth on the order of tens or hundreds of feet; this depth indicates the amount of vertical downdropping of Moenkopi blocks to be expected within a breccia pipe. Model calculations that suggest shallower anomaly depths could still indicate the presence of downdropped Moenkopi sediments and thus the potential for a breccia pipe. If the relatively recent shallow collapse features on the Kaibab Plateau (sink holes and possibly gypsum collapses) formed after the Moenkopi sediments were stripped off the plateau surface, then Moenkopi breccia would not be expected within these features, nor would there be an associated magnetic anomaly. Thus, the effective use of magnetic surveys over suspicious collapse features may be limited to the Kaibab surface, where Moenkopi sediments form the upper part of the downdropped breccia column.

Flanigan and others (1987) present preliminary results of a high-resolution aeromagnetic survey that was conducted over a section of the Coconino Plateau in the eastern Hualapai Reservation. Their data do not show any unique magnetic signature that coincides with the mapped collapse features, including three features that were surveyed by ground magnetometer and discussed in this paper-220, 569, and 570. The aeromagnetic data show no local magnetic anomaly at, or in the vicinity of, these three features; the data at these locations blend into the regional magnetic gradient. The surveys of Flanigan and others (1987) were flown $90 \mathrm{~m}$ above ground level with flight lines spaced $120 \mathrm{~m}$ apart; magnetic readings averaged every $22 \mathrm{~m}$ along each line. Apparently, either the aircraft was too high to detect the small amplitude of the magnetic anomalies of the pipes (attenuation due to distance) or the flight lines did not pass directly over any pipes. The aeromagnetic surveys did record magnetic anomalies that reflect several major faults shown on maps of the northeastern (Wenrich, Billingsley, and Huntoon, 1986) and southeastern (Billingsley and others, 1986) parts of the Hualapai Reservation.

\section{Methods}

The ground magnetometer surveys were conducted in June 1985 over two breccia pipes that have been confirmed by drilling-the Mohawk Canyon pipe and pipe 562-and over four suspected breccia pipes-220, 493, 569, and 570 (fig. 4). All of these surveys were conducted on the Coconino Plateau surface, which is capped by the Harrisburg Gypsiferous Member of the Kaibab Limestone.

Each ground magnetometer survey was run in a grid pattern, with 3 or 4 lines transecting the feature, and each line contained 20-30 evenly spaced readings. Station spacings for the individual readings along each line were adjusted to the size of the feature, from $10 \mathrm{~m}$ at feature 569 to $60 \mathrm{~m}$ at the larger fêature 493 . To ensure that adequate background data were obtained, each survey line extended outside the collapse on each side for at least the distance of the feature's radius; usually the lines extended outside the feature on each side for greater than its diameter.

An EDA PPM-350 (proton precession total field) ground magnetometer was used; the manufacturer claims a sensitivity of \pm 0.02 gamma and an absolute accuracy of $\pm 15 \mathrm{ppm}$ within the conditions under which it was operated. An accompanying base-station magnetometer (EDA PPM-400) recorded total field measurements every 15 seconds during the operation, which allowed the station readings to be corrected for both diurnal variations and reference field values. These corrections were calculated automatically in the field by connecting the portable and base-station magnetometers.

\section{GROUND MAGNETOMETER RESULTS}

\section{Mohawk Canyon Pipe}

The Mohawk Canyon pipe on the western side of Mohawk Canyon was discovered in 1983 and was rotary and core drilled during July-October 1984 by the U.S. Geological Survey in cooperation with the Bureau of Indian Affairs and the Hualapai Tribe (Wenrich and others, 1988). The upper $160 \mathrm{ft}$ of the pipe is exposed on two sides along the cliffs of Mohawk Canyon and a side tributary canyon (fig. 5). This exposure provides a crosssectional view of the beds of Harrisburg Gypsiferous Member of the Kaibab Limestone, which dip inward towards the center of the pipe, and of the gully that has been eroded along the circular ring fracture. Mineralized rock exposed on the surface within and adjacent to the inner ring fracture includes the secondary copper minerals malachite, azurite, brochantite, and chrysocolla, plus goethite pseudomorphs and molds of pyrite. Somewhere around the turn of the century, these copper minerals were mined from two adits dug into the inner ring fracture on the eastern side of the pipe. Hand samples from the ring fracture (including the adits) contain anomalous concentrations of $\mathrm{Ag}(110 \mathrm{ppm}), \mathrm{As}$ (400 ppm), Cu (1.4 percent), Fe (18 percent), $\mathrm{Hg}$ (0.3 ppm), Mo (140 ppm), Ni (70 ppm), Pb (1.2 percent), Sb (106 ppm), Se (350 ppm), U (50 ppm), V (190 ppm), and $\mathrm{Zn}$ (1.2 percent).

Five rotary and core holes were drilled into the Mohawk Canyon pipe; complete lithologic and geophysical logs are presented in Wenrich and others (1988). 


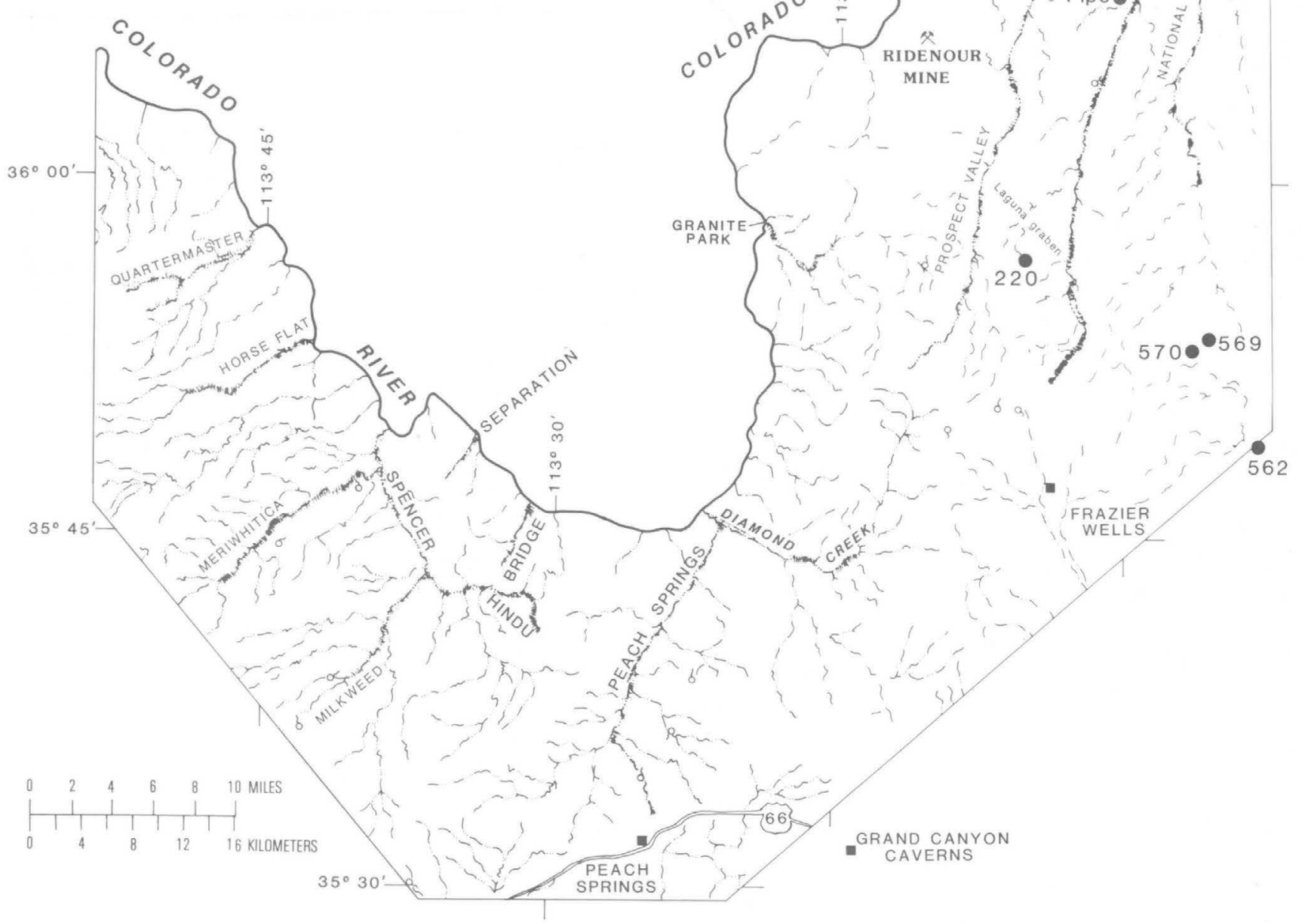

Figure 4. Map of the Hualapai Indian Reservation showing the collapse features surveyed by ground magnetometer-the Mohawk Canyon pipe, pipe 562, and collapse features 493, 220, 569, and 570. All of these features are plotted on 1:48,000scale topographic maps in Wenrich, Billingsley, and Huntoon (1986) and Billingsley and others (1986).

The porosity inherent within this brecciated column caused numerous drilling problems including loss of circulation, large water consumption, and the loss of several hundred feet of casing and the drill stem into a cavern that was apparently $30 \mathrm{ft}$ high. Brecciated core was recovered in the center of the pipe to a total depth of $1,012 \mathrm{ft}$. The core is variably oxidized and reduced and in places contains abundant pyrite, goethite, and limonite and minor galena, sphalerite, arsenopyrite, and bravoite. These minerals are common within economically mineralized (uranium) breccia pipes. One rotary hole, which reached a total depth of $1,335 \mathrm{ft}$, contained a $1-\mathrm{ft}$ interval of 0.52 percent $\mathrm{eU}_{3} \mathrm{O}_{8}$ at a depth of $1,191 \mathrm{ft}$ within a 20 -ft interval that averages 0.04 percent $\mathrm{eU}_{3} \mathrm{O}_{8}$. While this amount of uranium mineralization does not represent an orebody, the Mohawk Canyon pipe merits further drilling to fully evaluate its economic potential. Because of the uranium mineralization and mineral assemblage discovered at this pipe, it is presently considered to be one of the pipes on the Hualapai Reservation that have the greatest potential for an orebody. 


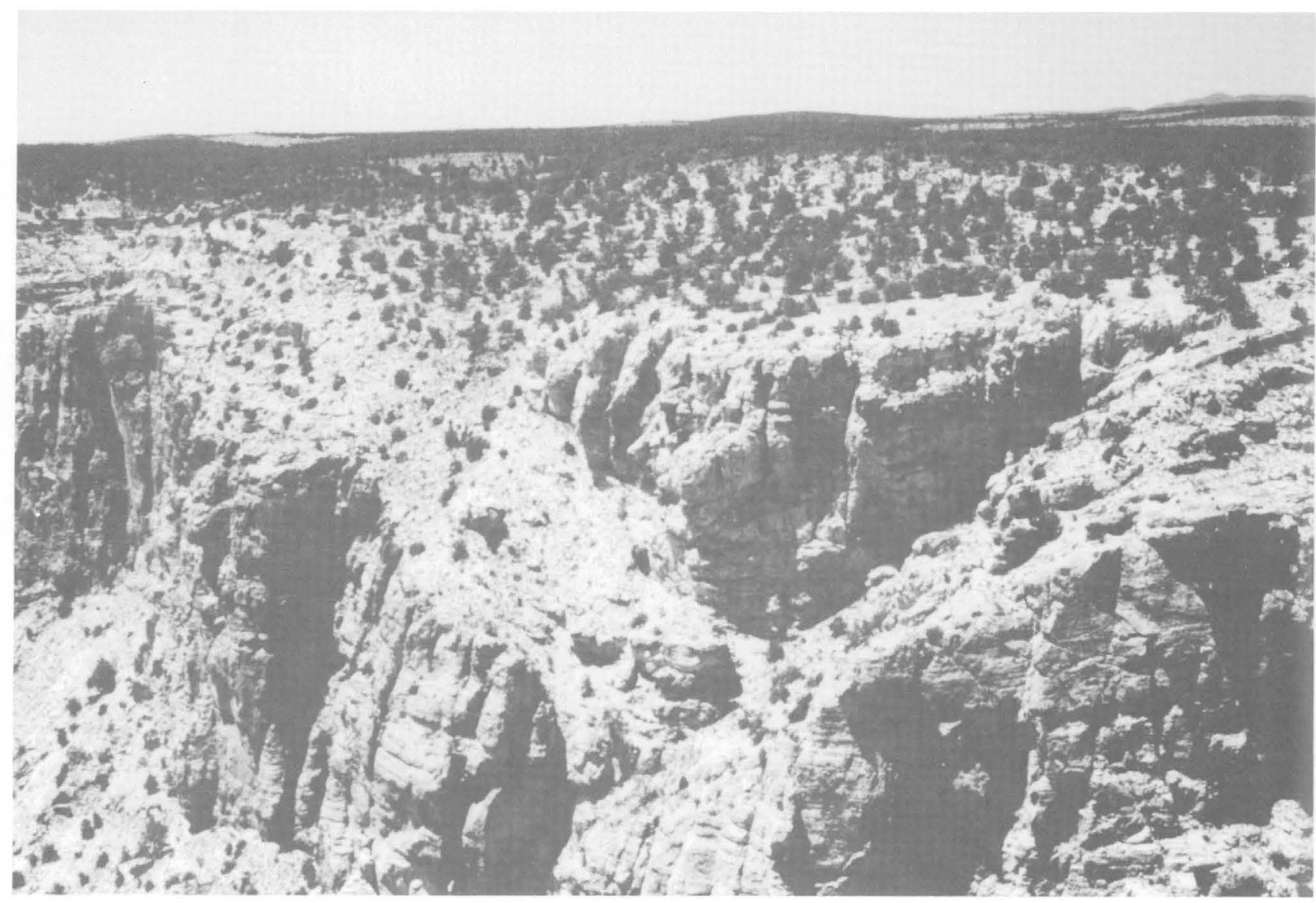

Figure 5. The Mohawk Canyon pipe, exposed on the western rim of Mohawk Canyon. Beds of Harrisburg Gypsiferous Member of the Kaibab Limestone dip towards the center of the pipe, and drainages accentuate the circular ring fracture. The central portion of the pipe (between the drainages) is about $650 \mathrm{ft}$ wide.

Four lines, each of which contained 21 magnetometer readings, were surveyed across the Mohawk Canyon pipe in 1985 subsequent to drilling (fig. 6). The pipe is bounded on the south and east by a shear cliff, thus limiting the survey. As shown in figure 7, the third and fourth magnetometer readings from the south on line 2 are suspiciously anomalous-the third reading is 7 standard deviations greater than the mean value of the ground magnetometer data set (table 1), and the fourth reading is 20 standard deviations greater than the mean - therefore these readings are considered to be erroneous. To record such high magnetic values, these readings must have been taken near metal objects (perhaps something that was buried during the postdrilling reclamation). These readings were therefore removed from the calculation of the contour and threedimensional plots shown in figure 8 . All other magnetometer values recorded at the pipe lie within one standard deviation of the data-set mean and were included in figure 8 .

The contouring of lines $1-4$, as shown in figure 8 , reveals a dipole anomaly within the breccia pipe. The
Table 1. Statistics for the data set of 531 ground magnetometer readings recorded during the study of six breccia pipes

[All values of total magnetic field are in gammas]

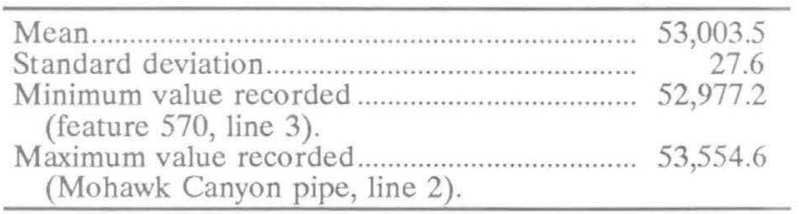

area of low magnetic values is positioned about N. $70^{\circ} \mathrm{E}$. of the area of high values. Because the magnetic declination in this region is N. $15^{\circ}$ E., the recorded anomaly does not exhibit the properties typical of a purely induced magnetic body (Dobrin, 1960, p. 275-277). Moenkopi Formation rocks or fragments were not recognized within the drill core or chip samples recovered from the pipe; the exact nature of the magnetic source being detected is uncertain. 


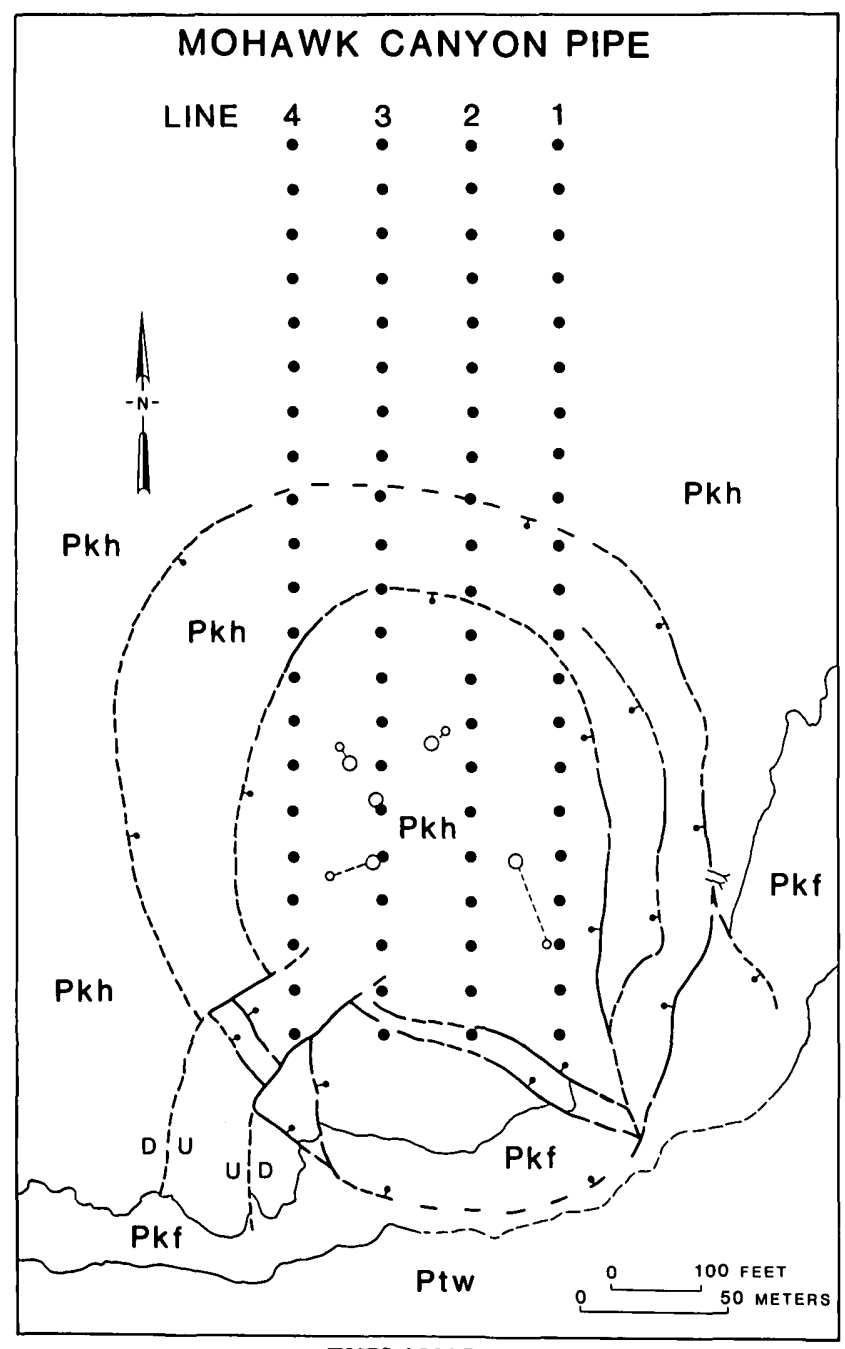

EXPLANATION

Pkh Permian Kaibab Limestone, Harrisburg Gypsiferous MemberCalcareous siltstone and fine-grained sandstone with minor micritic limestone; very pale orange; thin bedded to massive. Contains an 8-ft-thick marker bed composed of chert and chert breccia cemented by finely crystalline calcite. Forms alternating ledges and slopes. About $62 \mathrm{~m} \mathrm{(200} \mathrm{ft)} \mathrm{thick.}$

Pkf Permian Kalbab Limestone, Fossil Mountain Member-Very finely crystalline limestone containing abundant concentrically laminated chert nodules about $10 \mathrm{~cm}$ in diameter, light brownish gray; massive. About $74 \mathrm{~m}$ (240 ft) thick.

Ptw Permian Toroweap Formation, Woods Ranch MemberCalcareous sandstone and siltstone with minor micritic limestone and gypsum interbeds; pale red to grayish orange; thin bedded. About $62 \mathrm{~m}(200 \mathrm{ft})$ thick.

Contact, dashed where inferred

Surface trace of normal fault, dashed where inferred; ball and

$U$ Surface trace of reverse fault, dashed where inferred; $U$ on TOP upthrown side, $D$ on downthrown side

Drill hole with bottom location in map view

BOTீOM

- Location of magnetometer reading

$\prec \quad$ Adit

Figure 6. Geologic map of the Mohawk Canyon pipe showing the location of ground magnetometer readings and drill holes.

\section{Pipe 562}

Pipe 562 is located just southeast of the Hualapai Reservation, and, as with the other pipes surveyed, occurs on the surface of the Coconino Plateau. This pipe has a morphology that is typical for breccia pipes exposed on the Coconino Plateau surface-a raised rim (about 7 $\mathrm{ft}$ high) of rock outcrop of Harrisburg Gypsiferous Member of the Kaibab Limestone encloses a soilcovered, circular, depressed interior that consists of Moenkopi Formation sandstones and siltstones (fig. 9). Mineralized rocks, breccia, and obviously dipping beds are not present at the surface of this feature. Union Pacific Resources (formerly Rocky Mountain Energy, Inc.) has drilled the feature intermittently from 1984 to 1987; the results of the drilling indicate that the collapse is a uranium-mineralized breccia pipe.

Four lines of magnetometer readings were conducted across the mineralized pipe; each line contained 31-32 readings (fig. 10). The magnetometer survey was made subsequent to exploratory drilling at the pipe. As shown in figure 11, the three north-south lines (lines 1-3) display a local magnetic gradient which increases toward the south. The east-west line (line 4) shows a smaller, gradational magnetic increase toward the east. The anomalously high gamma value that is the fifth reading from the east on line 4 is 3.5 standard deviations above the mean and is thus considered to be an erroneous value-this reading was eliminated from the calculations that were used to create figure 12 .

In lines 2-4 anomalously low magnetic values occur over the collapsed interior of the pipe. A contour map of data from all four lines (fig. 12) shows that the centrally located magnetic lows are subtle relative to the local magnetic gradient, yet these anomalously low values are confined to an area that overlies the pipe.

The anomalous magnetic low that was detected over the pipe could be related to an underlying uranium orebody. A bleached (reduced) zone is generally associated with the uranium ore deposits in Grand Canyon breccia pipes. Because organic matter has been found in only minor occurrences within these pipes, Gornitz and others (1988) proposed that $\mathrm{Fe}^{+3}$ is reduced by $\mathrm{H}_{2} \mathrm{~S}$ and that $\mathrm{H}_{2} \mathrm{~S}$ is the most likely reducing agent for the ore deposition. Bleaching by $\mathrm{H}_{2} \mathrm{~S}$-bearing fluids would alter the detrital ilmenite and magnetite to nonmagnetic iron and titanium minerals, such as pyrite and leucoxene. Ilmenite depletion within bleached rocks has been observed in at least four mineralized breccia pipes, including the Mohawk Canyon pipe (also see Wenrich, 1986). In drill core recovered from the Mohawk Canyon pipe, a sharp oxidation/reduction contact occurs within the Permian Hermit Shale at a depth of $1,322 \mathrm{ft}$ (Wenrich and others, 1988). Petrographic studies by H.B. Sutphin (oral commun., 1987) reveal that the oxidized side of this 


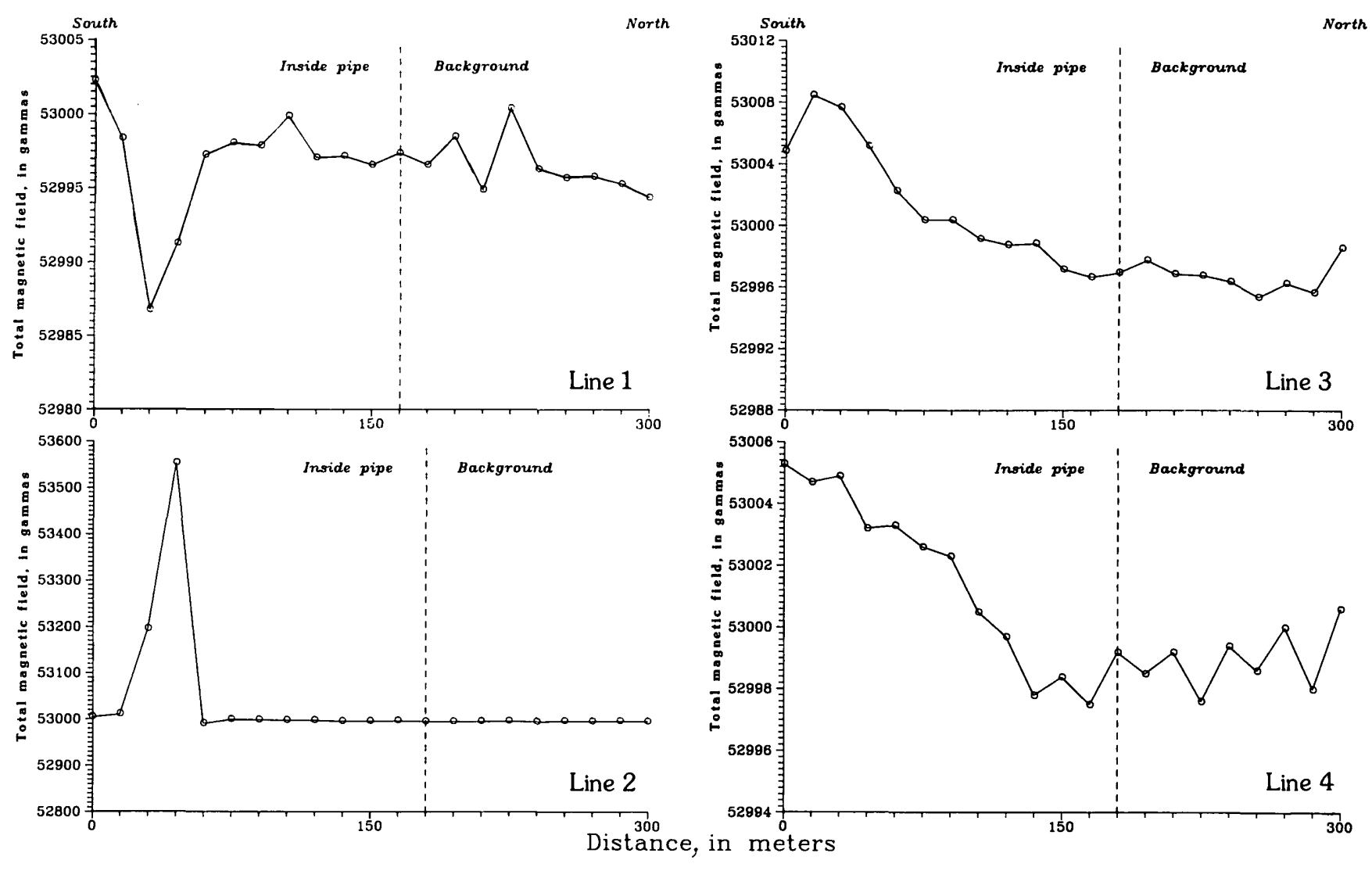

Figure 7. Total magnetic field profiles of ground magnetometer traverses at the Mohawk Canyon pipe. Lines 1-4 are indexed to figure 6. The anomalously high magnetic readings in line 2 (third and fourth from south) are 7 and 20 standard deviations, respectively, above the mean of the ground magnetometer data set and thus are considered to be erroneous values; these readings were not used in the calculation of figure 8 .

contact contains about 0.5 percent ilmenite framework grains, whereas the reduced/pyritic side does not contain even a trace of ilmenite; instead it has been replaced by leucoxene. This replacement could explain the magnetic low found over pipe 562, which is known to contain subsurface uranium minerals and reduced zones.

\section{Feature 220}

Feature 220 (fig. 13) is one of seven copper prospects within the region south of Laguna graben. These prospects were mined intermittently from the early 1900 's to the 1950's. They appear similar to the Jacob Lake prospect on the North Rim and the Anita Claims farther east, which consist of malachite- and azurite-impregnated chert breccias. Recent mapping indicates that these breccias are not tectonic or channel deposits but rather are intraformational breccias formed during deposition of the Harrisburg Gypsiferous Member of the Kaibab Limestone. The breccias near feature 220 may be related to movement along the Toroweap and Aubrey faults during Kaibab deposition, as the breccias appear to thicken adjacent to the faults.

The excavated copper-rich areas of these prospects are roughly circular, but the prospects lack other classic pipe morphologies, such as concentrically inward dipping beds. The geochemistry of rocks and soil taken from these prospects suggests that these copper deposits may have been formed by the same mineralizing fluids that created ore deposits in mineralized breccia pipes. Samples taken from these prospects contain anomalous concentrations of $\mathrm{Ag}, \mathrm{As}, \mathrm{Co}, \mathrm{Cu}, \mathrm{Mo}, \mathrm{Ni}, \mathrm{Pb}, \mathrm{Se}, \mathrm{U}$, and $\mathrm{Zn}-\mathrm{a}$ trace element assemblage similar to that found in mineralized breccia pipes. Most element concentrations are as high as those measured in uranium ore-bearing pipes, for example, $100 \mathrm{ppm} \mathrm{Co,} 300 \mathrm{ppm} \mathrm{Ni,} 410 \mathrm{ppm}$ $\mathrm{Pb}, 4,200 \mathrm{ppm} \mathrm{Zn}$, and $41 \mathrm{ppm} \mathrm{U}$. There remains the possibility that these prospects are epigenetic copper deposits located over breccia-pipe orebodies in an intraformational breccia that was readily favorable for hosting copper mineralization. 


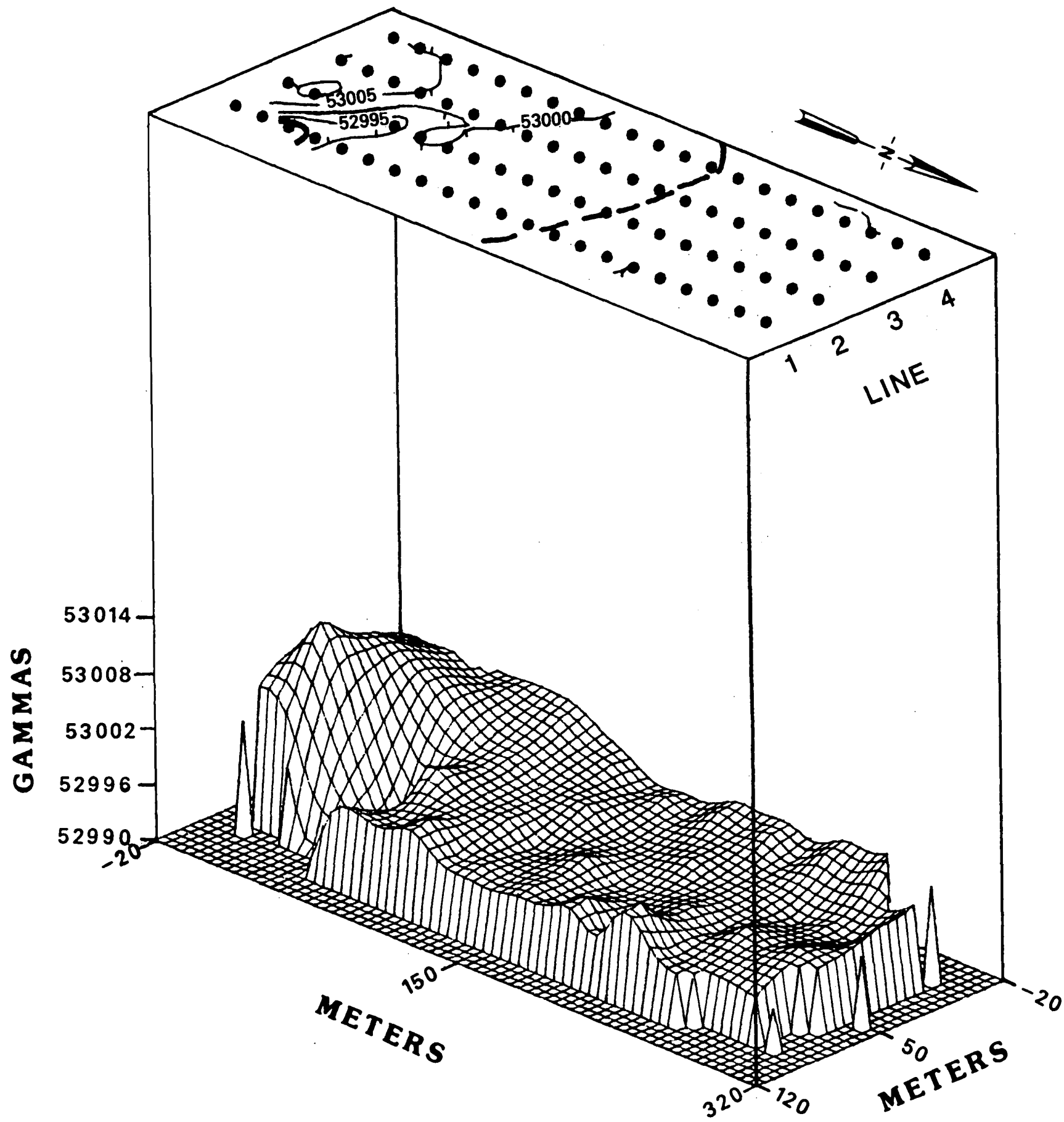

Figure 8. Three-dimensional model and contour plot of the ground magnetometer data shown in figure 7 for the Mohawk Canyon pipe. Heavy dashed line represents the outline of the breccia pipe. Note the magnetic dipole overlying the pipe.

Five rotary holes were drilled into feature 220 by Western Nuclear Inc.; the drilling reports are stored in the Hualapai Tribal office files. Four of the holes were less than $200 \mathrm{ft}$ deep, and hole 2 reached a total depth of $297 \mathrm{ft}$. Hole 4 showed $100 \mathrm{cps}$ (counts per second) radiation between 20 and $30 \mathrm{ft}$, but gamma logs of the remaining holes showed radiation less than $40 \mathrm{cps}$.
Sparse copper and some limonite and hematite alteration were found in the core. The shallow depth reached by these holes did not permit us to determine whether a breccia pipe occurs at depth.

Flanigan, Mohr, and others (1986) conducted a single northeast-southwest profile of AMT soundings across feature 220 . Two conductive zones that reach the 


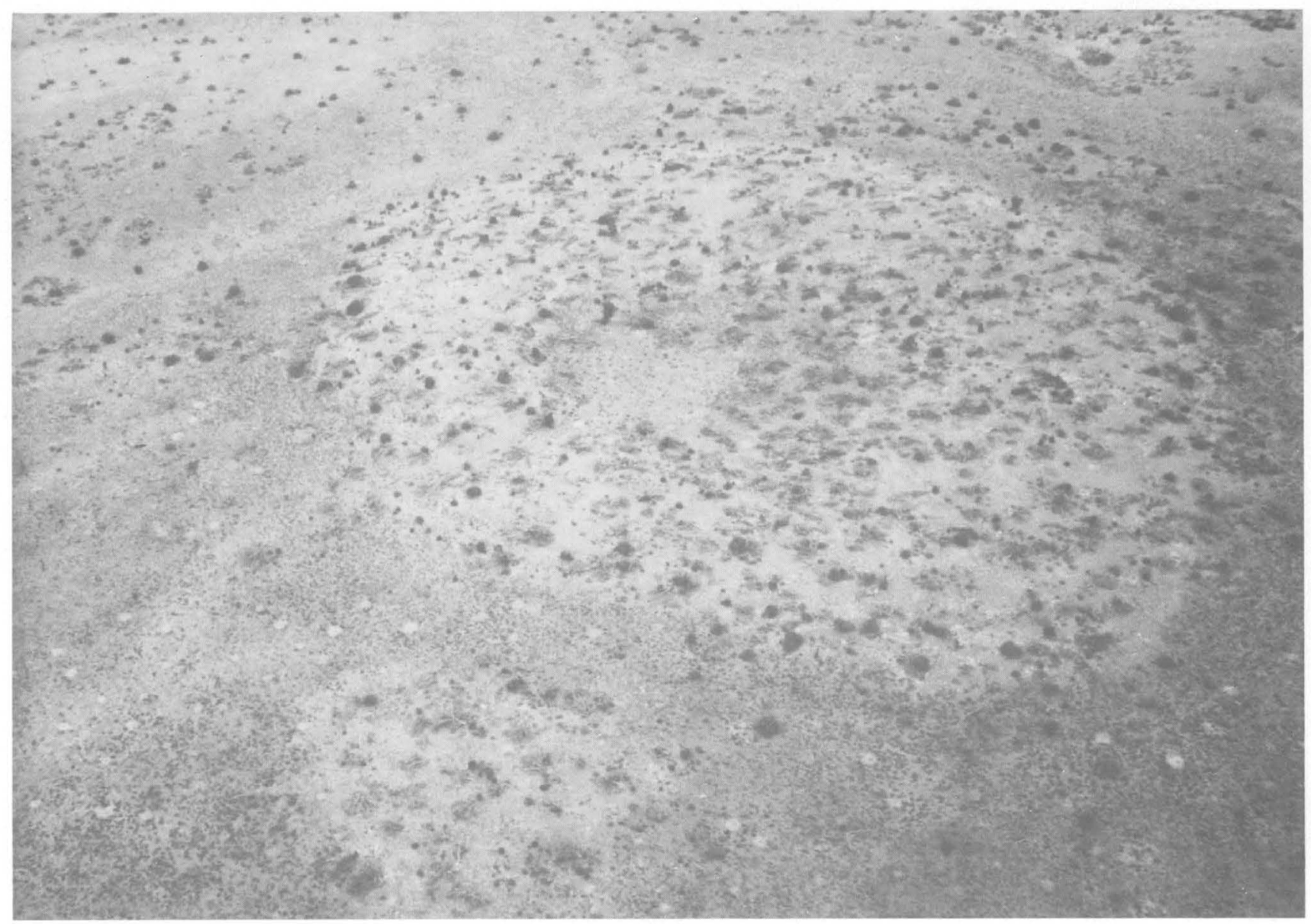

Figure 9. Pipe 562 has a morphology that is typical for breccia pipes exposed on the Coconino Plateau-a raised rim of Harrisburg Gypsiferous Member outcrop encloses a soil-covered, circular depression that is about $100 \mathrm{~m}$ in diameter. View is to the southwest.

surface were detected at stations located just northeast and southwest of the excavated pit area. A third conductive zone, which underlies resistive rocks, was recorded near the center of the pit area. Flanigan, Mohr, and others (1986) considered this profile data "not definitive", again leaving the genesis of the copper deposits in question.

Three lines, each of which contained 22 ground magnetometer readings, were surveyed at feature 220 , as shown in figure 14. A high magnetic reading was recorded near the northern end of every survey line (fig. 15). The single-point positive anomaly near the northern end of line 2 is slightly more than one standard deviation above the mean; all other readings at the site occur within one standard deviation of the mean. Contouring the data for lines 1-3 (fig. 16) shows the nearly linear area of high magnetic values north of the prospect, plus a magnetic low near the excavated pit. These data suggest two hypotheses regarding a subsurface structure at feature 220: (1) The copper deposit may extend at least another
$250 \mathrm{~m}$ north of the excavated pit; and (or) (2) an actual breccia pipe may be to the north, and the copper mineralizing fluids migrated along the permeable intraformational breccia and formed the small copper deposit to the south of the breccia pipe.

\section{Feature 493}

Feature 493 (fig. 17), which is one of the largest collapses mapped on the Hualapai Reservation, has a diameter of about $500 \mathrm{~m}$. The collapse is truncated on its western side by Mohawk Canyon. The collapse has a striking morphology - a central hill is encircled by a moat that is in turn surrounded by higher hills of Harrisburg Gypsiferous Member of the Kaibab Limestone. The mound-shaped central hill is rimmed by a circular ring of steeply inward dipping $\left(>45^{\circ}\right)$ red and white beds that enclose a center of dark-red soil. The dark-red soil is most probably an erosional remnant of downdropped 


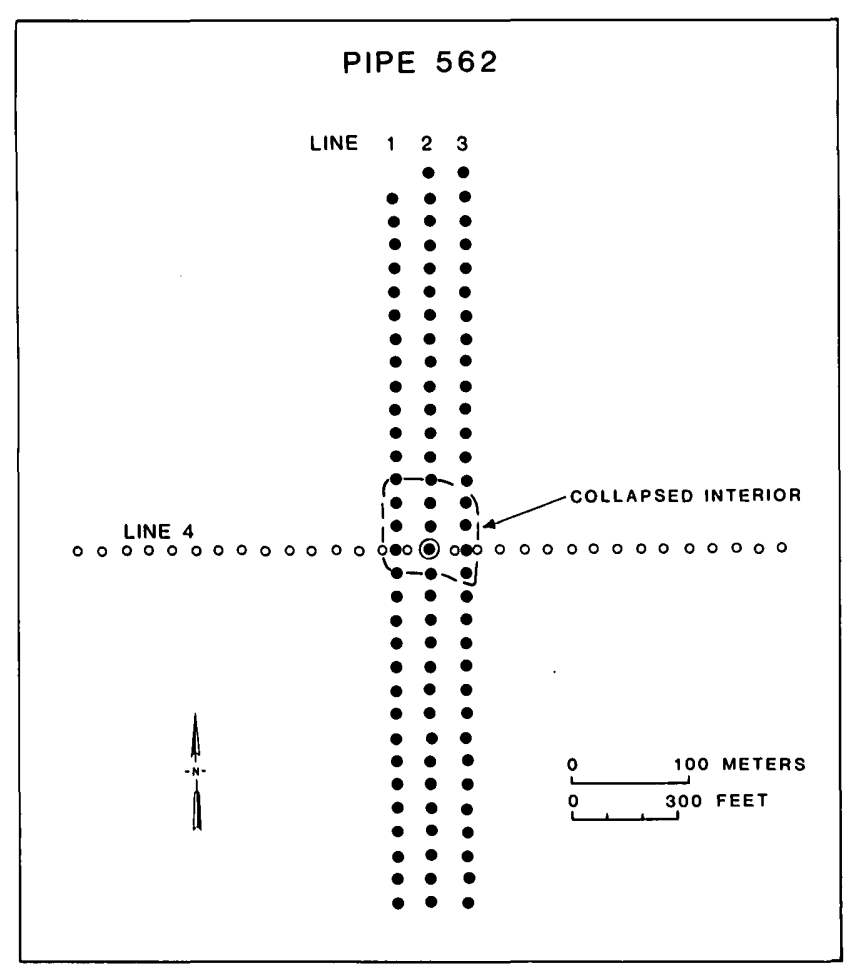

Figure 10. Map showing the location of ground magnetometer readings at pipe 562. The dashed line represents the outline of the soil-covered, collapsed interior. The raised rim (not shown) that encircles the collapsed interior is about $75 \mathrm{~m}$ wide.

Moenkopi Formation. The soil within the moat area appears to be weathered Kaibab Limestone.

Along the cliff face, on the western edge of the collapse, the gypsiferous Woods Ranch Member of the Toroweap Formation thins to zero thickness below the collapse. On the same cliff face a cave has formed below the collapse within the Fossil Mountain Member of the Kaibab Limestone. These solution features are evidence of the increased fluid movement and dissolution that occurred through this collapse. The increased dissolution also explains the large enclosing moat area, which is probably the result of lateral fluid movement into gypsiferous and calcareous units adjacent to the breccia pipe (as discussed earlier in the section on collapse features on the Hualapai Indian Reservation).

Chemical analyses of rock samples from the central hill and from altered beds on the western edge of the collapse reveal few anomalous elements. Flanigan, Mohr, and others (1986) conducted AMT soundings within feature 493. The AMT data along a north-south traverse shows a very conductive zone about $50 \mathrm{~m}$ wide beneath the central hill (resistivity plots of the zone resemble the morphology of the Washington Monument). This conductive zone is enclosed by resistive rocks that are surrounded by a conductive zone near the rim of the feature. These data support a model in which the central hill with inward-dipping beds represents the breccia pipe, and the moat area represents the gypsum collapse formed by dissolution of the Toroweap adjacent to the pipe.

As shown in figure 18, three north-south lines, each of which contained 23 ground magnetometer readings, were conducted across feature 493 . A shorter line with 10 readings, line 4 , traversed the small central hill and crossed lines 1-3 at their midpoints.

All the magnetic values (fig. 19) recorded at feature 493 lie within one standard deviation of the ground magnetometer data-set mean value. The most significant anomaly recorded here occurs in the vicinity of the central hill. An anomalous magnetic high was detected over the middle of the central hill, adjacent to an area of an anomalous magnetic low which is positioned $50 \mathrm{~m}$ to the east, just outside the eastern rim of the central hill. These data (fig. 20) suggest that a magnetic body or source is associated with the central hill structure. More closely spaced north-south readings across and around the central hill would better delineate the orientation of this anomaly. As mentioned earlier, AMT soundings strongly suggest that the central hill represents the surface manifestation of a breccia pipe. The dark-red soil on the surface of the hill is likely downdropped Moenkopi sediments, which should exhibit a relatively higher magnetic response than the surrounding Kaibab Limestone. Thus; the magnetic anomaly recorded at the central hill may reflect the more magnetic Moenkopi sediments that collapsed into the breccia pipe.

\section{Feature 569}

The surface morphology of feature 569 (fig. 21) makes it one of the collapse structures most likely to overlie a breccia pipe in the National Tank area of the Hualapai Reservation (Wenrich, Billingsley, and Van Gosen, 1986). The collapse is a peanut-shaped depression enclosed by a low rim of Harrisburg Gypsiferous Member of the Kaibab Limestone. The interior of the collapse is covered by soil and brush, and the outside is rocky and covered with Kaibab float and some juniper and pinyon pines. The limited outcrop that rims the collapse appears to contain only flat-lying beds.

A helium soil-gas survey was conducted over the collapse in March 1985; mean helium concentrations measured inside the depression were similar to concentrations obtained in a background area located $1,500 \mathrm{ft}$ to the southwest (Reimer, 1985). A second helium survey was run over the collapse in June 1985 (G.M. Reimer, personal commun., 1986). This time two samples from the eastern side of the depression were anomalous, but too few background samples were taken to adequately define "anomalous." 


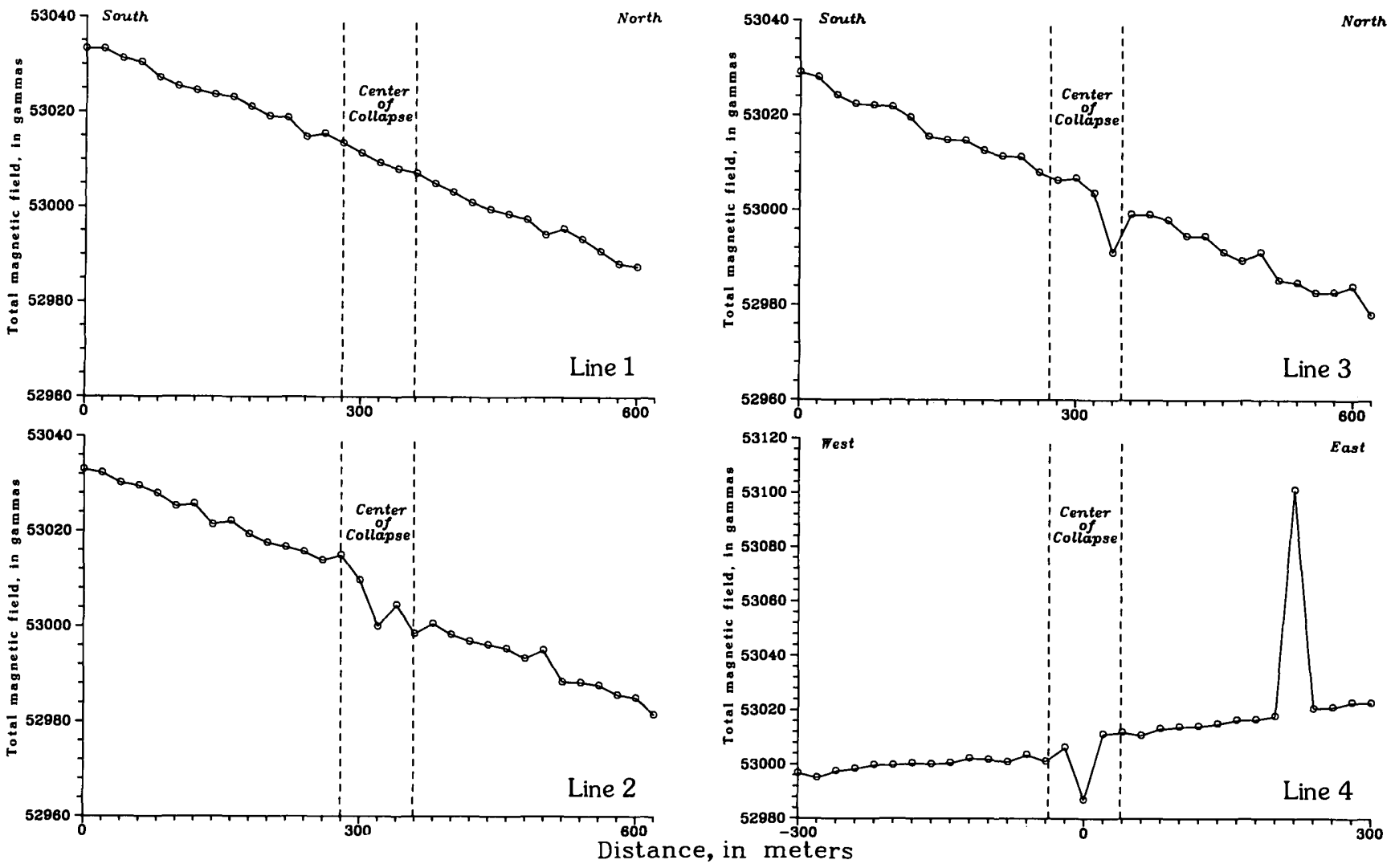

Figure 11. Total magnetic field profiles of ground magnetometer traverses at pipe 562. Lines 1-4 are indexed to figure 10. The anomalously high gamma value that is the fifth reading from the east on line 4 is considered to be a false value because it is 3.5 standard deviations above the mean; this reading was eliminated in the calculation of figure 12.

A northwest-southeast line of AMT soundings was measured across the long dimension of feature 569 by Flanigan, Mohr, and others (1986). A small conductive zone was recorded just southeast of the center of the collapse. Because of the small size of this zone, Flanigan, Mohr, and others (1986) considered the feature a "questionable breccia pipe." It is worth noting that the small conductive zone is located near the area of Reimer's two "anomalous" helium soil-gas samples.

Four lines of ground magnetometer readings were recorded at feature 569 (fig. 22), including two northsouth lines that contained 26 and 27 readings and two east-west lines that contained 26 and 29 readings. All the values recorded here fall within one standard deviation of the mean. All four lines showed anomalously high magnetic values (fig. 23) that occur either within the depressed interior or near the rim of the collapse. Contouring of feature 569 data (fig. 24) reveals two areas of anomalously high values, two areas of anomalously low values, and a local magnetic gradient that increases towards the north. The overall pattern suggests that at least two dipole anomalies may be associated with the collapse, but if so, would be positioned in different orientations than those of bodies with strictly induced magnetization. The surface morphology of the collapse and the presence of two dipole anomalies suggest that the feature represents the surface manifestation of two intergrown breccia pipes. While the data indicate that the collapsed interior of feature 569 is magnetically anomalous, the source of magnetism is uncertain; typical Moenkopi sediments have not been identified on the surface of the collapse.

North-south line 2 (fig. 23), which displays the most pronounced dipole anomaly recorded during this study (Telford and others, 1976), was chosen for modeling of the magnetic source. SAKI, a Fortran program developed by Webring (1985), was used to model the data. The best-fit model (fig. 25) placed the top of the magnetic source at ground level. The magnetic source continued to a depth of at least $50 \mathrm{~m}$ (these closely spaced data could not be modeled for greater depths). The model approximated a rectangular prism (there was not enough information available for a more detailed shape) with a diameter of $30 \mathrm{~m}$ (the width of the collapse feature along line 2 is about $50 \mathrm{~m}$ ). The model also fit best when the magnetic body was tilted slightly to the south at depth. Magnetic susceptibilities were estimated to be in the range of $10^{-5}$ to $10^{-4} \mathrm{emu} / \mathrm{cm}^{3}$ (electro- 


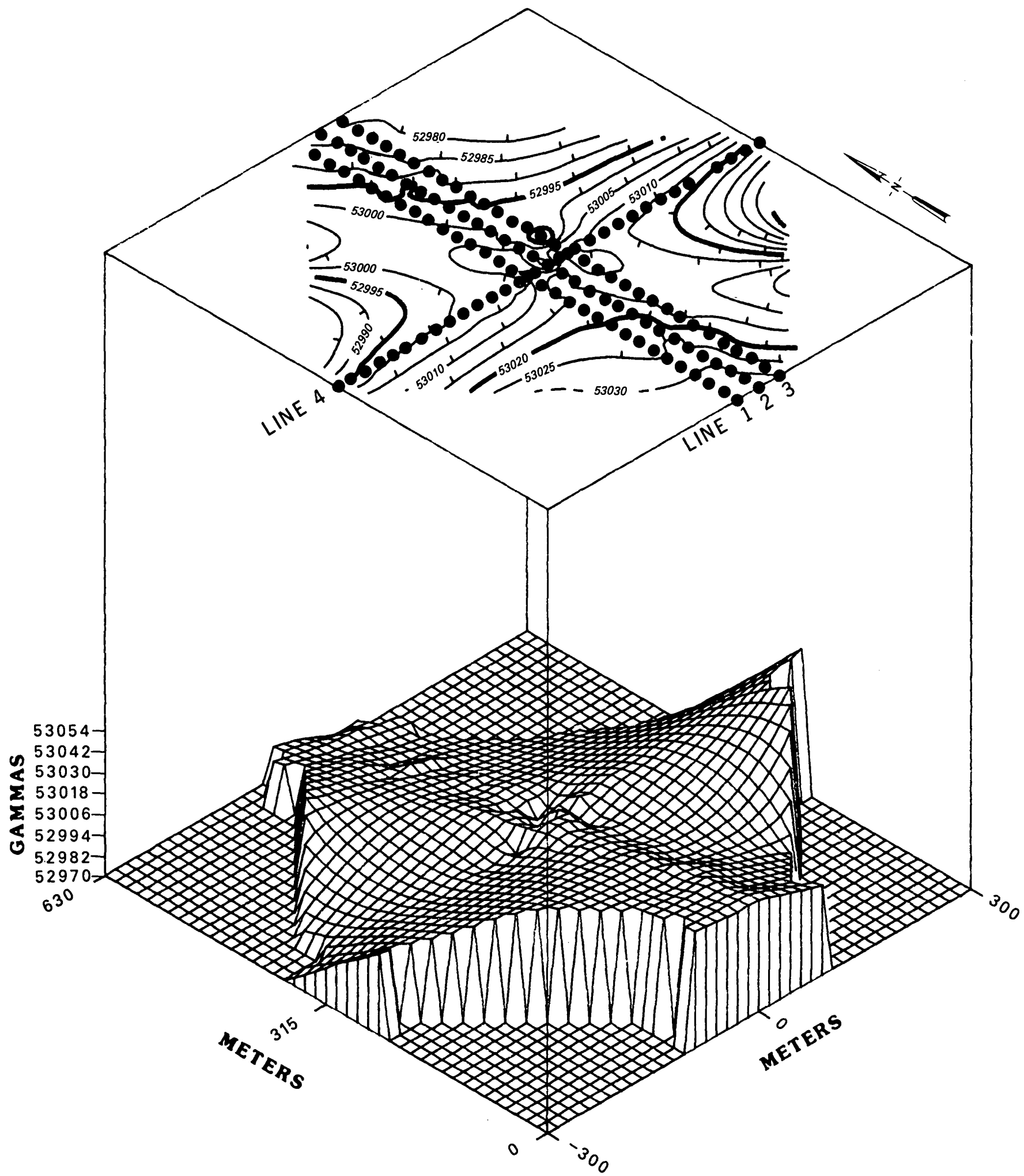

Figure 12. Three-dimensional model and contour plot of the ground magnetometer data shown in figure 11 for pipe 562 . Note the area of low magnetic values over the collapsed interior of the pipe. 


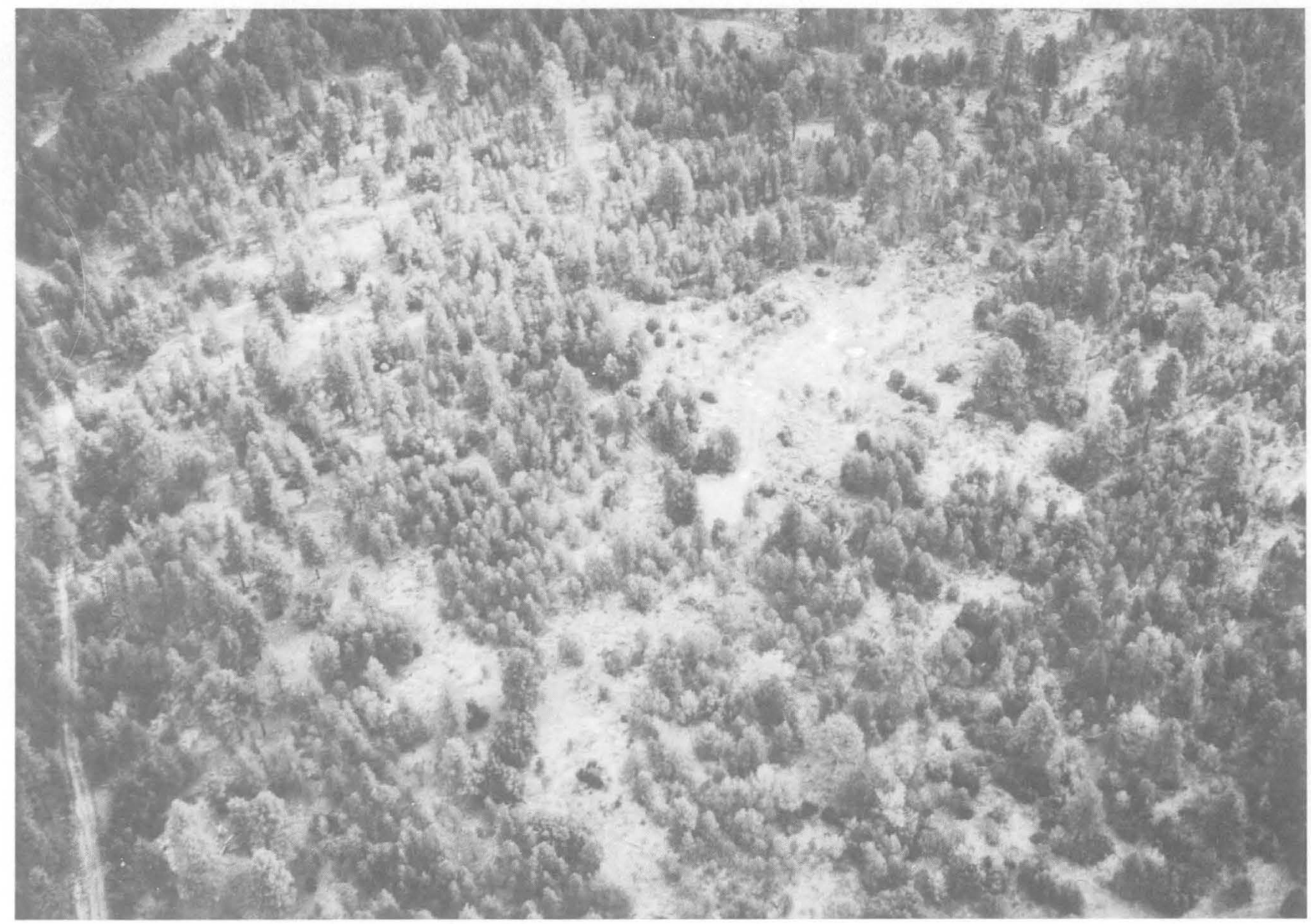

Figure 13. Feature 220 is a bulldozed copper prospect (about $50 \mathrm{~m}$ in diameter) among Ponderosa pine trees. The copper minerals appear to have formed a stratiform mineralized layer within an intraformational chert breccia. It is uncertain whether this deposit overlies a breccia pipe. View is to the northeast.

magnetic units per $\mathrm{cm}^{3}$ ), which are typical values for detrital magnetism in sedimentary rocks (Clark, 1966).

In summary, modeling of the magnetic data from feature 569 reveals that the magnetic source, which is slightly smaller than the surface diameter of the collapse, begins at the surface and extends to a depth of at least 50 m. The magnetic susceptibilities recorded are typical of detrital magnetism in sedimentary rocks.

\section{Feature 570}

Feature 570 is very similar in surface morphology to pipe 562 described earlier, except that 570 is breached on one side (fig. 26). Its center is soil covered and surrounded on three sides by a circular rim about $15 \mathrm{ft}$ high of rocks of the Harrisburg Gypsiferous Member. The rim is rockier than the interior of the collapse, but outcrop is generally absent throughout the feature. The morphology alone makes Feature 570 one of the best prospects for an underlying breccia pipe in the National
Tank area of the Hualapai Reservation (Wenrich, Billingsley, and Van Gosen, 1986).

Flanigan, Mohr, and others (1986) conducted AMT soundings across feature 570 along east-west and north-south lines. Both lines recorded a conductive zone about $100 \mathrm{~m}$ in diameter that is centered in the middle of the collapse. The zone was recorded vertically about 900 $\mathrm{m}$ through the entire depth of the profile. The conductive zone appears to split at depth, and the more conductive section plunges to the south and east. The data suggest an underlying, plunging breccia pipe; this plunge must be considered in future drilling plans for the pipe.

Three north-south lines, each of which contained 22 ground magnetometer readings, were traversed across the collapse (fig. 27). The magnetic data recorded here are the least variable data of all the features surveyed. A constant magnetic gradient appears in every survey line (fig. 28); the magnetic values increase toward the north.

All the magnetic values recorded at feature 570 lie within one standard deviation of the mean (fig. 28). The 


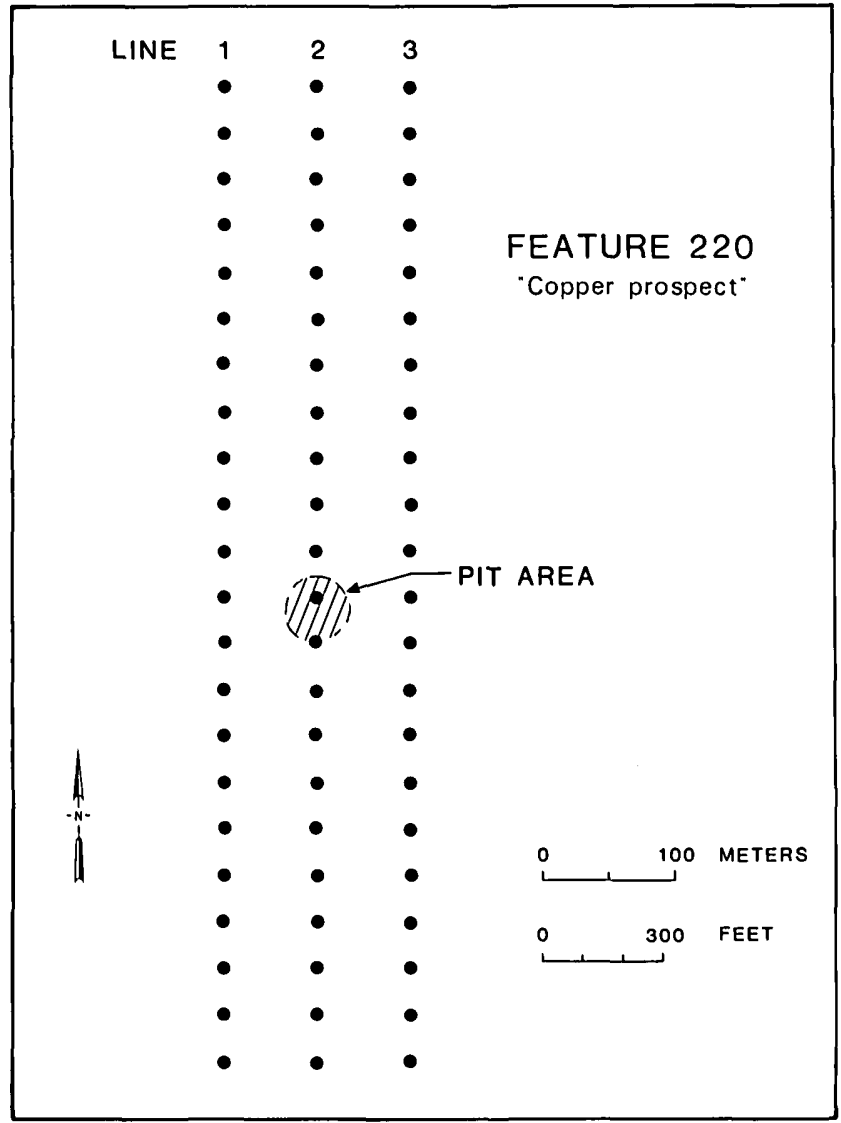

Figure 14. Map showing the location of ground magnetometer readings at feature 220. Patterned area represents the extent of the excavated pit.

data here appear featureless and lack the localized, magnetically anomalous areas that are associated with the other collapses surveyed. Two subtle magnetic lows (fig. 29) occur just south of the collapsed interior of 570 in lines 2 and 3. Yet similar subtle lows also appear north of and outside the collapse in lines 1 and 3. Overall, the magnetic data at 570 do not appear to suggest the presence of an underlying breccia pipe as do the AMT soundings at this site by Flanigan, Mohr, and others (1986).

\section{CONCLUSIONS}

Magnetic anomalies were detected at five of the six collapses surveyed:

(1) The Mohawk Canyon pipe contains surface copper mineralization and subsurface uranium mineralization that has been confirmed by rotary drilling and coring. A dipole anomaly was recorded over the pipe, with the area of low magnetic values positioned about $\mathrm{N}$. $70^{\circ} \mathrm{E}$. of the high value area.
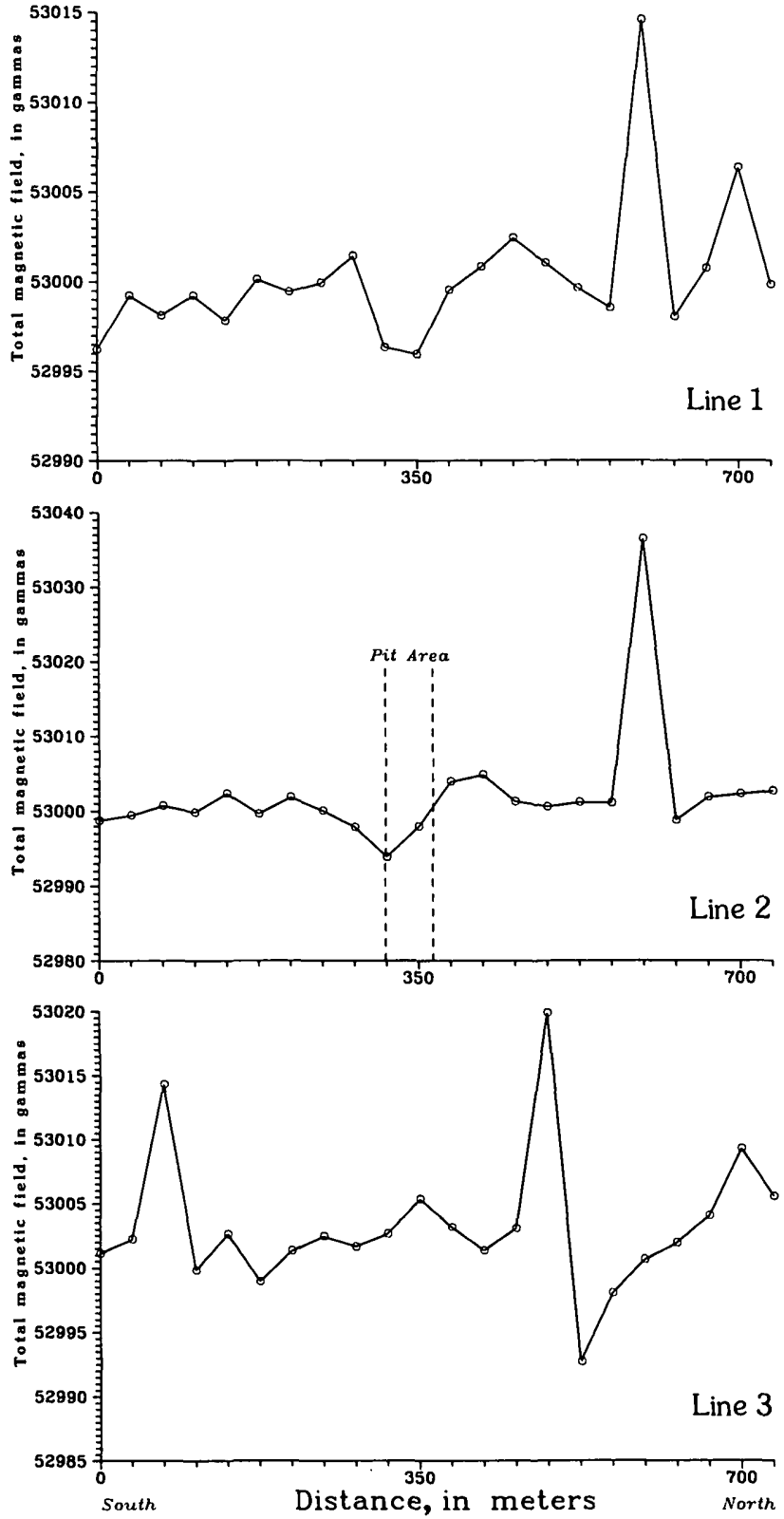

Figure 15. Total magnetic field profiles of ground magnetometer traverses at feature 220. Lines 1-3 are indexed to figure 14. The single high gamma reading on the north end of line 2 is slightly more than one standard deviation above the mean; all other readings at the site lie within the standard deviation.

(2) Exploratory drilling at pipe 562 indicates that the collapse is a uranium-mineralized breccia pipe. Anomalously low magnetic values were detected over a portion of the collapsed interior of the pipe.

(3) Feature 220 appears to be a stratiform copper deposit within an intraformational breccia. The deposit may overlie a breccia pipe; the exact structure of the deposit is uncertain. A nearly linear area of high 


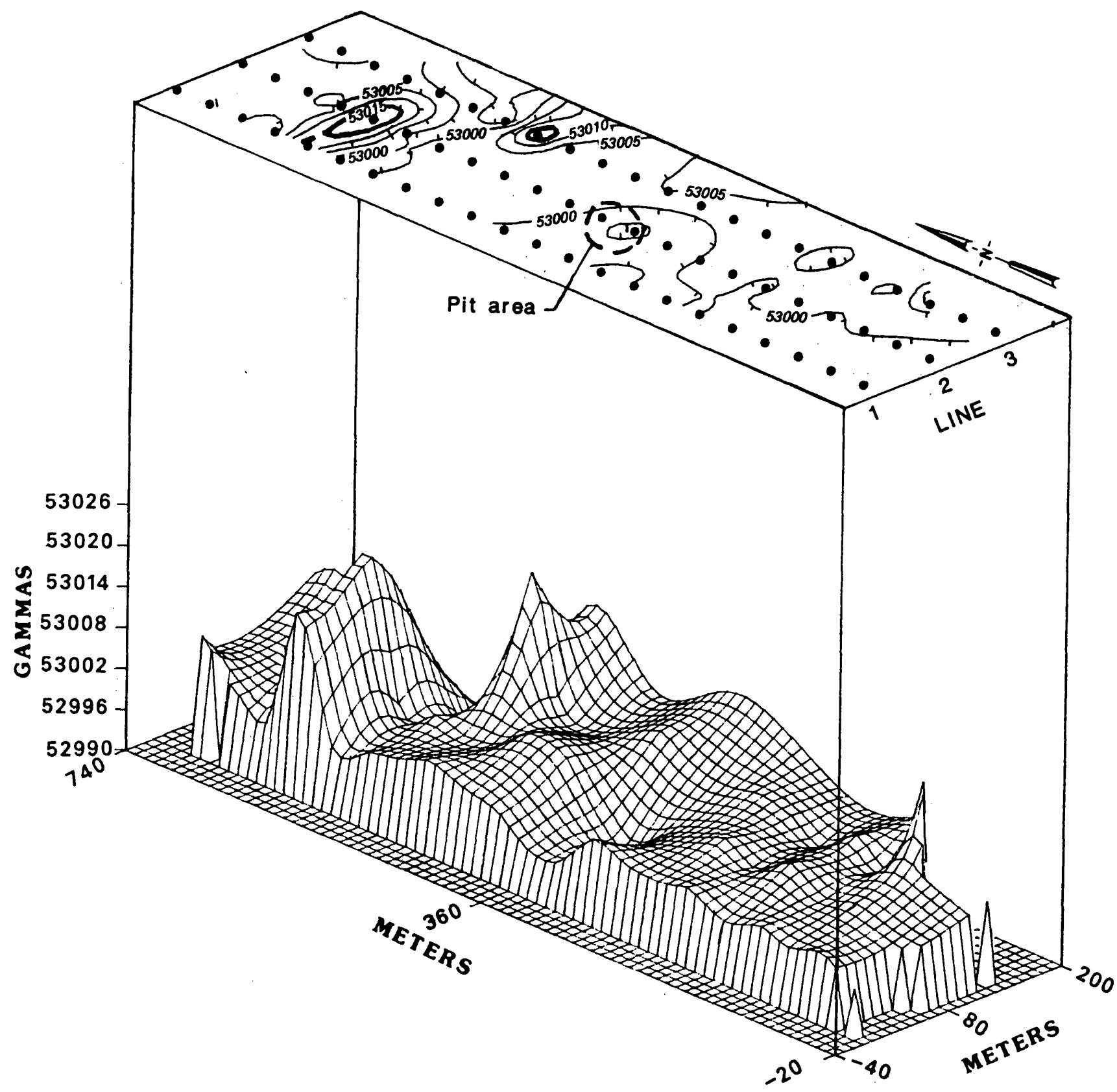

Figure 16. Three-dimensional model and contour plot of ground magnetometer data shown in figure 15 for feature 220 . Note the area of high magnetic values north of the feature and the magnetic low in the vicinity of the excavated pit.

magnetic values occurs north of the feature, and an area of low magnetic values exists in the vicinity of the excavated pit.

(4) AMT soundings and field observations at feature 493 suggest that the small hill in the center of the collapse, which is rimmed by steeply inward dipping beds, represents a breccia pipe, which is enclosed by a gypsum collapse moat. The magnetic data reveal an east-westoriented dipole anomaly associated with the central hill.
(5) The surface morphology of feature 569 indicates that some type of collapse is present here. Helium soil-gas surveys and AMT soundings were inconclusive. The magnetic data shows two areas of anomalously high values and two areas of anomalously low values within and bordering the collapse, which suggests that this peanut-shaped depression may represent the surface manifestation of two intergrown breccia pipes. 


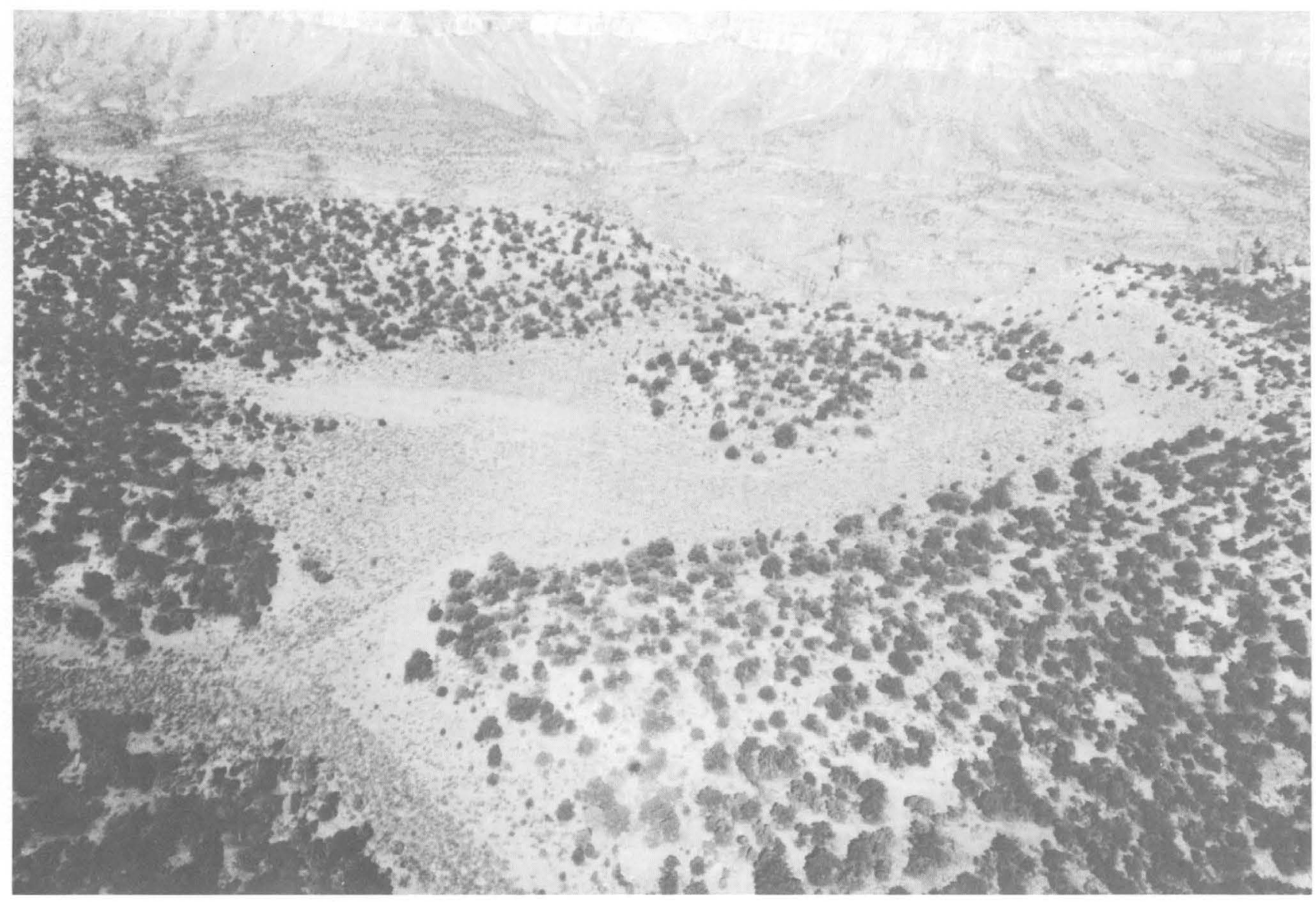

Figure 17. Feature 493. The collapse contains a small hill rimmed by circular, inward-dipping beds, which is encircled by a moat, in turn surrounded by higher hills. Entire feature, rim to rim, is about $500 \mathrm{~m}$ wide as viewed to the west with Mohawk Canyon in the background.

(6) The surface morphology of feature 570 indicates a collapse that is about three-fourths enclosed by a circular, raised rim. AMT soundings suggest an underlying, plunging breccia pipe. The magnetic data reveal a featureless, constant local magnetic gradient that lacks the magnetic anomalies associated with the other collapses surveyed.

A dipole magnetic anomaly recorded along line 2 at feature 569 was modeled to determine the magnetic source. The best-fit model reveals that: (1) The magnetic source begins at the surface and extends to a depth of at least $50 \mathrm{~m},(2)$ the source is slightly smaller than the surface diameter of the collapse, and (3) the magnetic susceptibilities recorded are typical of detrital magnetism in sedimentary rocks.

Petrographic studies indicate the Moenkopi Formation contains a higher concentration of heavy minerals-including detrital grains of ilmenite, magnetite, and magnetite-ilmenite (ilmenite is most abundant) - than the underlying Kaibab Limestone and Toroweap Formation. The \pm 0.02 -gamma sensitivity of the ground magnetometer used in this study allowed detection of subtle magnetic anomalies. These anomalies suggest magnetic susceptibilities that are typical for ilmenite- and magnetite-bearing sedimentary rocks. The dipole magnetic anomalies detected over collapses may reflect Moenkopi sediments of relatively higher magnetic content that have been downdropped into Kaibab Limestone host rock. Surface exposures of typical Moenkopi rocks are visible only at feature 493, but the precision of the instrument used requires little magnetic source to be present for detection. Thus, magnetic surveys over suspicious collapse features should be useful on plateau surfaces capped by the Kaibab Limestone, where Moenkopi sediments could downdrop into the breccia column.

The anomalously low magnetic values recorded over the interior of pipe 562 and near the center (excavated pit) of feature 220 require a different explanation. These anomalous magnetic lows could reflect underlying mineral deposits. Bleached (reduced) zones are generally associated with the uranium ore deposits in Grand Canyon breccia pipes. A depletion of magnetic minerals-specifically ilmenite-has been 


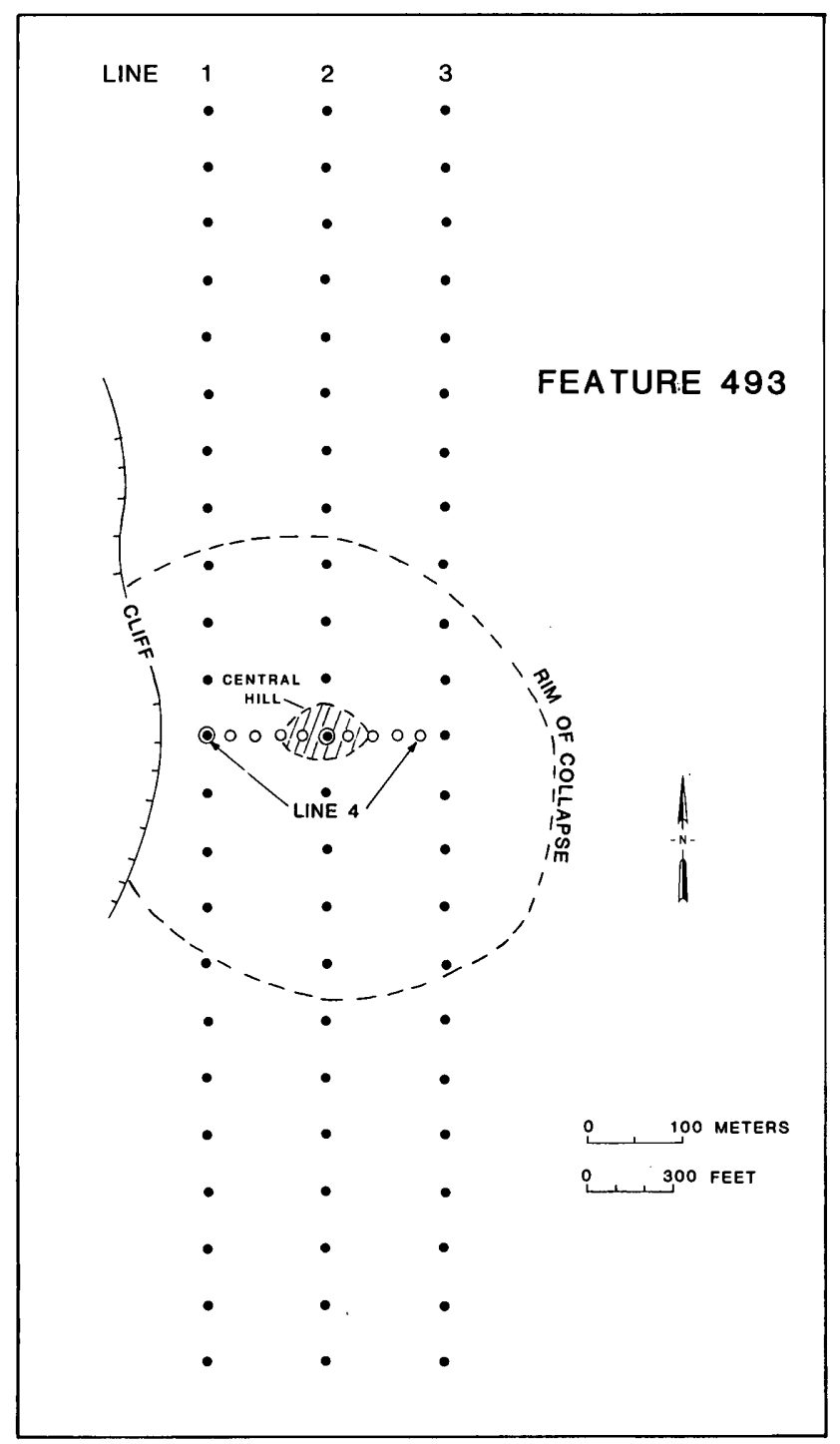

Figure 18. Map showing the location of ground magnetometer readings at feature 493. The "rim of collapse" represents the crest of the hills surrounding the moat.

observed within the bleached rocks of mineralized pipes. Framework ilmenite grains, which compose about 0.5 percent of the oxidized breccia, are replaced by nonmagnetic iron and titanium minerals, such as pyrite and leucoxene, within the reduced/pyritic breccia. This type of ilmenite depletion could explain the magnetic lows found over pipe 562 (known to contain subsurface uranium minerals and reduced rock) and over feature 220 (copper deposit).

The magnetic declination in this region is $\mathrm{N} .15^{\circ} \mathrm{E}$. None of the dipole anomalies recorded in this study were oriented as would be expected for a strictly induced magnetic source, that is, aligned with the area of low magnetic values positioned about N. $15^{\circ} \mathrm{E}$. of the area of high magnetic values.
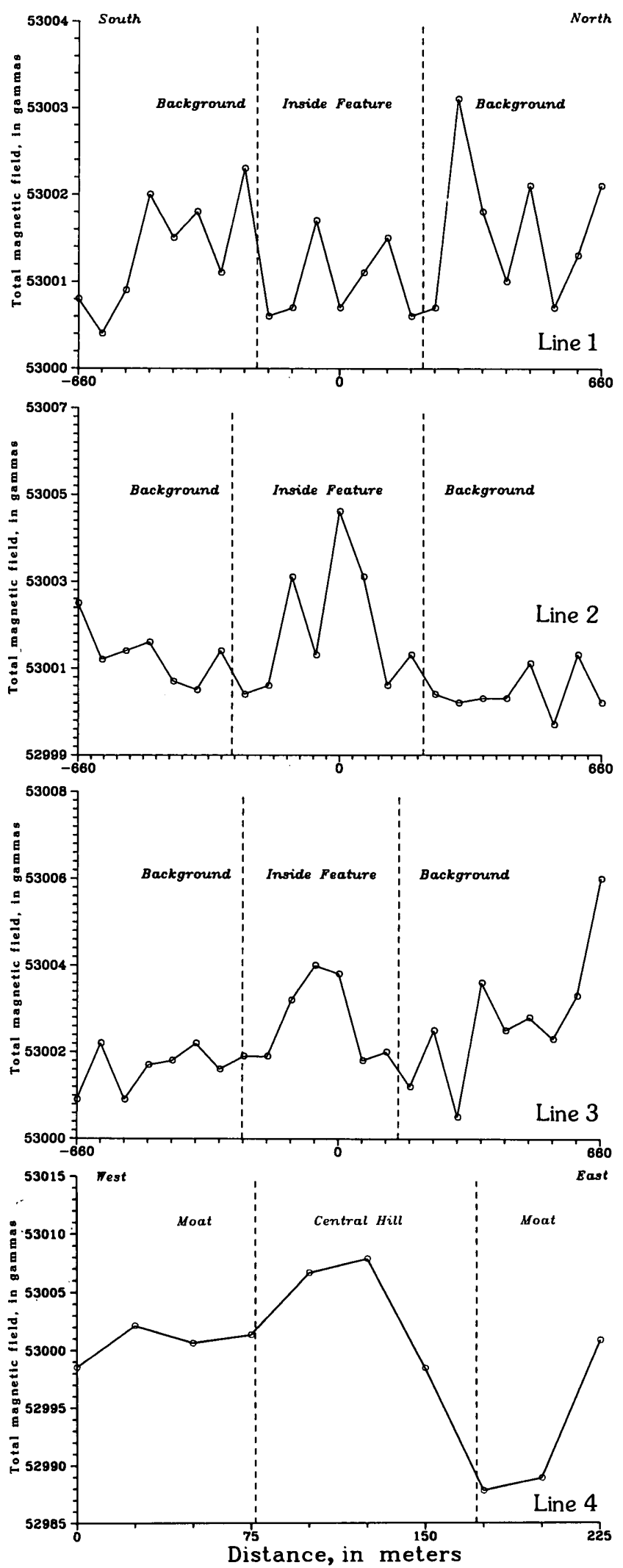

Figure 19. Total magnetic field profiles of ground magnetometer traverses at feature 493 . Lines $1-4$ are indexed to figure 18 . Note the anomaly detected in line 4 . 


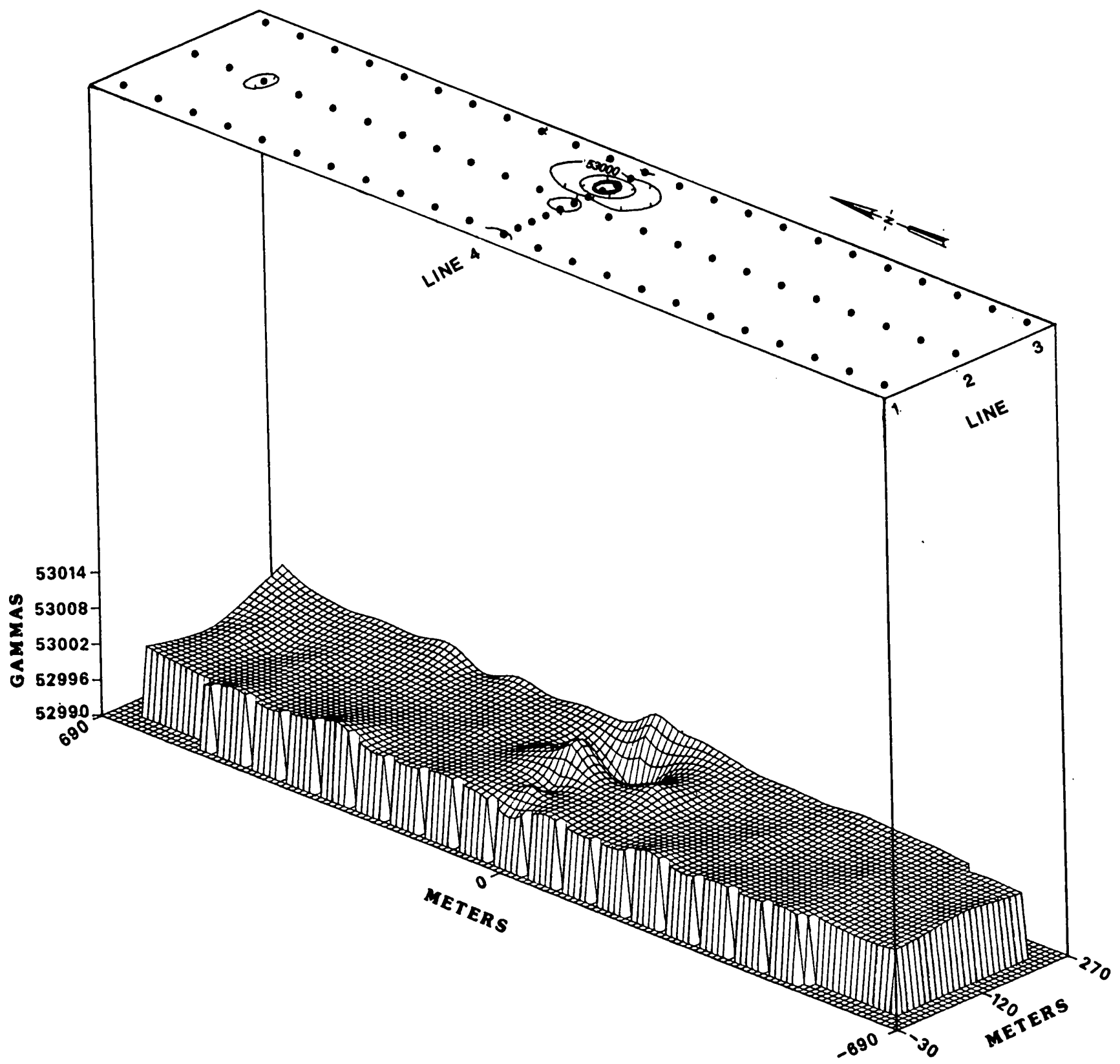

Figure 20. Three-dimensional model and contour plot of ground magnetometer data shown in figure 19 for feature 493 . Note the east-west-oriented dipole anomaly associated with the central hill.

Future drilling of the collapse features investigated in this report might help to evaluate the effectiveness of ground magnetometer surveys in distinguishing breccia pipes from shallow, unmineralized collapses. Although ground magnetometer surveys alone may not provide conclusive evidence for a subsurface, mineralized pipe, they seem useful in choosing drilling targets when combined with other geophysical techniques (primarily AMT).

\section{ACKNOWLEDGMENTS}

This study was part of larger project funded by the Bureau of Indian Affairs in cooperation with the Hualapai Indian tribe. We appreciate the conscientious manuscript reviews and suggestions by Viki Bankey (U.S. Geological Survey) and Dick Mead (Union Pacific Resources). We are also grateful to Hoyt B. Sutphin for sharing his prior experiences with ground magnetometer surveys over breccia pipes and especially for providing his 


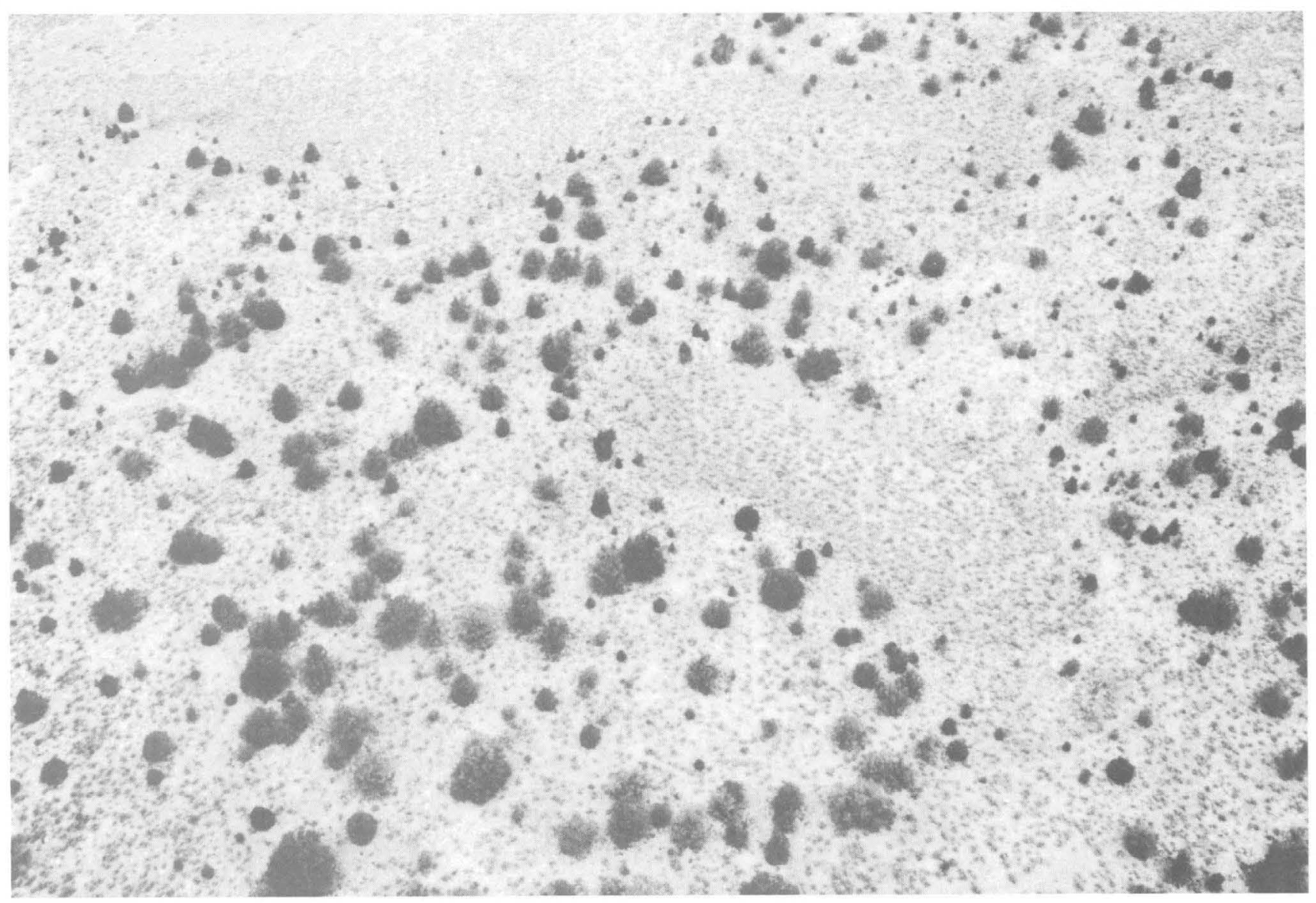

Figure 21. Feature 569 is a soil- and brush-covered depression, about $80 \mathrm{~m}$ long, rimmed by sparse outcrops of flat-lying rocks of the Harrisburg Gypsiferous Member. Sparse juniper and pinyon pines surround the collapse. View is to the north.

consultation concerning the petrology of the rock units within the region. We thank Lindrith $\mathrm{E}$. Cordell for sharing his knowledge on magnetic anomalies and Vicki Bankey and Michael W. Webring for the computer modeling of the data. Joseph F. Mascarenas and Erin Nelson participated in the field collection of the data.

\section{REFERENCES CITED}

Bernstein, L.R., 1986, Geology and mineralogy of the Apex germanium-gallium mine, Washington County, Utah: U.S. Geological Survey Bulletin 1577, 9 p.

Billingsley, G.H., 1986, Relations of the Surprise Canyon and Watahomigi Formations to breccia pipes in the Grand Canyon, Arizona: Geological Society of America Abstracts with Programs, v. 18, no. 5, p. 342.

Billingsley, G.H, and Beus, S.S., 1985, The Surprise Canyon Formation-An Upper Mississippian and Lower Pennsylvanian(?) rock unit in the Grand Canyon, Arizona, in Stratigraphic notes, 1984: U.S. Geological Survey Bulletin 1605-A, p. A27-A33.

Billingsley, G.H., Wenrich, K.J., and Huntoon, P.W., 1986, Breccia pipe and geologic map of the southeastern Hualapai Indian Reservation and vicinity, Arizona: U.S.
Geological Survey Open-File Report 86-458-B, 26 p., 2 plates, scale 1:48,000.

Bowles, C.G., 1965, Uranium-bearing pipe formed by solution and collapse of limestone, in Geological Survey research, 1965: U.S. Geological Survey Professional Paper 525-A, p. A12.

Bromfield, C.S., 1952, Copper House Mining Company, Mohave County, Arizona, access road copper geology: Defense Minerals Exploration Administration, AR 126, $5 \mathrm{p}$.

Casebolt, L.L., Faurote, J.M., and Pillmore, D.M., 1986, Underground geologic evaluation-Hack Canyon breccia pipe uranium ore body, Mohave County, Arizona: Geological Society of America Abstracts with Programs, v. 18 , no. 5 , p. 345 .

Chenoweth, W.L., 1986, The Orphan Lode mine, Grand Canyon, Arizona, a case history of a mineralized, collapse-breccia pipe: U.S. Geological Survey Open-File Report 86-510, 126 p.

Chenoweth, W.L., and Blakemore, P.P., 1961, The Riverview mine, Coconino County, Arizona: Plateau, v. 33, p. 112-114.

Clark, S.P., Jr., 1966, Handbook of physical constants: Geological Society of America Memoir 97, p. 548. 


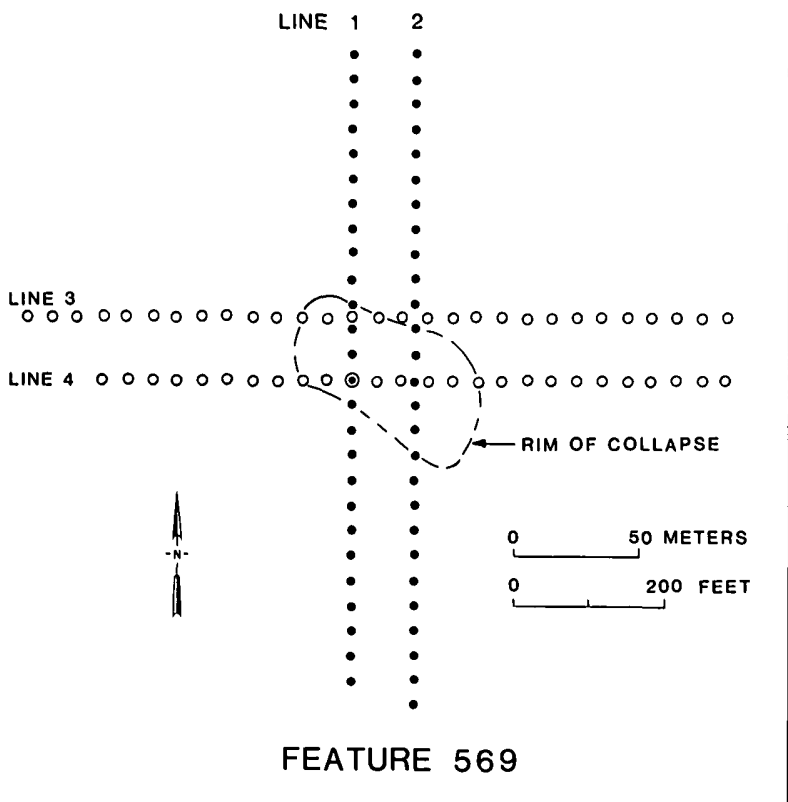

Figure 22. Map showing the location of ground magnetometer readings relative to the rim of feature 569 .

Dobrin, M.B., 1960, Introduction to geophysical prospecting [2d ed.]: New York, McGraw-Hill, p. 275-277.

Flanigan, V.J., Mohr, Pam, Tippens, Charles, and Senterfit, Michael, 1986, Electrical character of collapse breccia pipes on the Coconino Plateau, northern Arizona: U.S. Geological Survey Open-File Report 86-521, 50 p.

Flanigan, V.J., Tippens, C.L., Senterfit, M.R., and Mohr, P.J., 1986, Geophysical exploration criteria for collapse breccia pipes, northern Arizona: Geological Society of America Abstracts with Programs, v. 18, no. 5, p. 355.

Flanigan, V.J., Webring, M.W., and Mohr, P.J., 1987, Preliminary geologic interpretation of the high resolution aeromagnetic map of part of the Coconino Plateau, Hualapai Indian Reservation, Arizona: U.S. Geological Survey Open-File Report 87-53, 8 p., 2 plates.

Gornitz, Vivien, and Kerr, P.F., 1970, Uranium mineralization and alteration, Orphan mine, Grand Canyon, Arizona: Economic Geology, v. 65, no. 7, p. 751-768.

Gornitz, V., Wenrich, K.J., Sutphin, H.B., and Vidale-Buden, R., 1988, Origin of the Orphan mine breccia pipe uranium deposit, Grand Canyon, Arizona, in Vassiliou, A.H., Hausen, D.M, and Carson, D.J., eds., Process mineralogy VII-As applied to separation technology: Warrendale, Penn., Metallurgical Society, p. 281-301.

Hasbrouck, W.P., 1986, Results of shallow siesmic studies across the collapse breccia pipe sites on the Hualapai Reservation, northern Arizona: Geological Society of America Abstracts with Programs, v. 18, no. 5, p. 360.

Huntoon, P.W., 1986, Ground water flow directions in Colorado Plateau breccia pipes: Geological Society of America Abstracts with Programs, v. 18, no. 5, p. 363.
Kinkel, A.R., Jr., 1951, Preliminary report on the Apex and Paymaster mines, Washington County, Utah: U.S. Geological Survey Open-File Report 90, 9 p.

Krewedl, D.A., and Carisey, J.C., 1986, Contributions to the geology of uranium mineralized breccia pipes in northern Arizona: Arizona Geological Society Digest, v. 16, p. 179-186.

Landais, P., 1986, Geochemical analyses of the organic matters associated with the breccia pipes in the Grand Canyon area: Geological Society of America Abstracts with Programs, v. 18, no. 5, p. 389.

Ludwig, K.R., Rasmussen, J.D., and Simmons, K.R., 1986, Age of uranium ores in collapse-breccia pipes in the Grand Canyon area, northern Arizona: Geological Society of America Abstracts with Programs, v. 18, no. 5, p. 392.

Miller, R.D., 1954, Copper-uranium deposits at the Ridenour mine, Hualapai Indian Reservation, Coconino County, Arizona, Pt. 1: U.S. Atomic Energy Commission, RME-2014, p. 1-18.

Osterstock, R.W., Tillman, C.G., and Young, W.E., 1954, Defense Minerals Exploration Administration Docket 3075: J. and M. Leasing Co., Cox and Ross Claims, Copper Mountain Mine, Mohave County, Ariz., 33 p.

Rasmussen, J.D., Cunningham, C.G., and Gautier, A.M., 1986, Primary fluid inclusions in sphalerite from the Hack 1 and 2 mines, Mohave County, Arizona: Geological Society of America Abstracts with Programs, v. 18, no. 5, p. 404.

Reimer, G.M., 1985, Helium soil-gas survey of a collapse feature on the Hualapai Indian Reservation, Arizona: U.S. Geological Survey Open-File Report 85-394, 15 p.

Reimer, G.M., and Been, J.M., 1986, Helium soil-gas surveys of collapse features on the Hualapai Indian Reservation, Arizona: Geological Society of America Abstracts with Programs, v. 18, no. 5, p. 404.

Standish, R.P., and Schmeling, B.D., 1986, The use of transient electromagnetics in exploration for mineralized breccia pipes: Geological Society of America Abstracts with Programs, v. 18, no. 5, p. 415-416.

Stewart, J.H., Poole, F.G., and Wilson, R.F., 1972, Stratigraphy and origin of the Triassic Moenkopi Formation and related strata in the Colorado Plateau region, with $a$ section on Sedimentary petrology, by R.A. Cadigan: U.S. Geological Survey Professional Paper 691, p. 61.

Sutphin, H.B., 1986, Occurrence and structural control of collapse features on the southern Marble Plateau, Coconino County, Arizona: Flagstaff, Ariz., Northern Arizona University M.S. thesis, 139 p.

Sutphin, H.B., and Wenrich, K.J., 1983, Structural control of breccia pipes on the southern Marble Plateau, Arizona: U.S. Geological Survey Open-File Report 83-908, 6 p., 2 sheets, scale 1:50,000.

1986, Redwall Limestone joint control on Orphan mine-type breccia pipes on the Marble Plateau, Arizona: Geological Society of America Abstracts with Programs, v. 18 , no. 5 , p. 416 .

Telford, W.M., Geldart, L.P., Sheriff, R.E., and Keys, D.A., 1976, Applied Geophysics: Cambridge, Great Britain, Cambridge University Press, p. 155-157. 


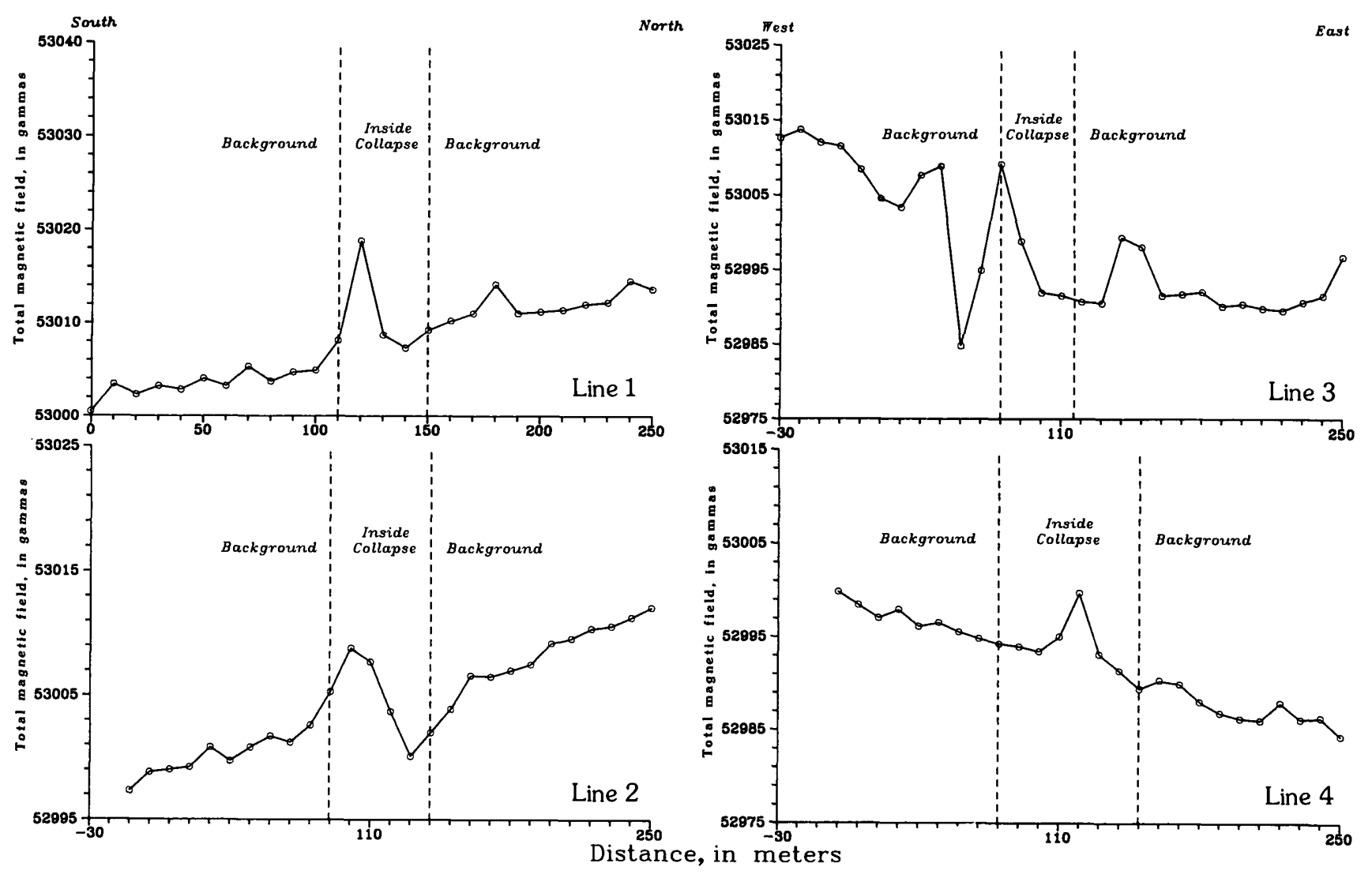

Figure 23. Total magnetic profiles of ground magnetometer traverses at feature 569. Lines $1-4$ are indexed to figure 22. Note the dipole anomalies in lines 2 and 3 and the high gamma values in lines 1 and 4 . All values recorded here fall within the standard deviation of the magnetometer data set.

Verbeek, E.R., Grout, M.A., and Van Gosen, B.S., 1988, Structural evolution of a Grand Canyon breccia pipe-The Ridenour copper-vanadium-uranium mine, Hualapai Indian Reservation, Coconino County, Arizona: U.S. Geological Survey Open-File Report 88-6, $75 \mathrm{p}$.

Verbeek, E.R., Grout, M.A., Van Gosen, B.S., and Sutphin, H.B., 1987, Structure of the Apex mine, southwestern Utah: Geological Society of America Abstracts with Programs, v. 19, no. 5, p. 340.

Watkins, T.A., 1975, The geology of the Copper House, Copper Mountain, and Parashant breccia pipes, western Grand Canyon, Mohave County, Arizona: Golden, Colo., Colorado School of Mines M.S. thesis, $91 \mathrm{p}$.

Webring, Michael, 1985, SAKI-A Fortran program for generalized linear inversion of gravity and magnetic profiles: U.S. Geological Survey Open-File Report 85-122, 108 p.

Wenrich, K.J., 1985, Mineralization of breccia pipes in northern Arizona: Economic Geology, v. 80, no. 6, p. 1722-1735. 1986, Geochemical exploration for mineralized breccia pipes in northern Arizona, U.S.A.: Applied Geochemistry, v. 1 , no. 4 , p. $469-485$.

Wenrich, K.J., Billingsley, G.H., and Huntoon, P.W., 1986, Breccia pipe and geologic map of the northeastern Hualapai Indian Reservation and vicinity, Arizona: U.S. Geological Survey Open-File Report 86-458-A, 29 p., 2 plates, scale 1:48,000.
1987, Breccia pipe and geologic map of the northwestern Hualapai Indian Reservation and vicinity, Arizona: U.S. Geological Survey Open-File Report 86-458-C, 29 p., 2 plates, scale 1:48,000.

Wenrich, K.J., Billingsley, G.H., and Van Gosen, B.S., 1986, The potential for breccia pipes in the National Tank area, Hualapai Indian Reservation, Arizona: U.S. Geological Survey Open-File Report 86-592-A, 45 p.

Wenrich, K.J., and Pratt, L.M., 1985, Paragenesis and conditions of formation of ore minerals from metalliferous breccia pipes, northern Arizona: Geological Society of America Abstracts with Programs, v. 17, no. 7, p. 747.

Wenrich, K.J., Van Gosen, B.S., Balcer, R.A., Scott, J.H., Mascarenas, J.F., Bedinger, G.M., and Burmaster, Betsi, 1988, A mineralized breccia pipe in Mohawk CanyonLithologic and geophysical logs: U.S. Geological Survey Bulletin 1683-A, 66 p.

Wenrich, K.J., Verbeek, E.R., Sutphin, H.B., Van Gosen, B.S., and Modreski, P.J., 1987, The Apex mine, Utah-A Colorado Plateau-type solution-collapse breccia pipe, in Sachs, J.S., ed., USGS research on mineral resources, 1987; program and abstracts: U.S. Geological Survey Circular 995, p. 73-74, 76-77.

Wheeler, R.L., 1986, Selecting reliable alignments of mapped points-Structural control of breccia pipes on the Marble Plateau, northern Arizona: Geological Society of America Abstracts with Programs, v. 18, no. 5, p. 422. 


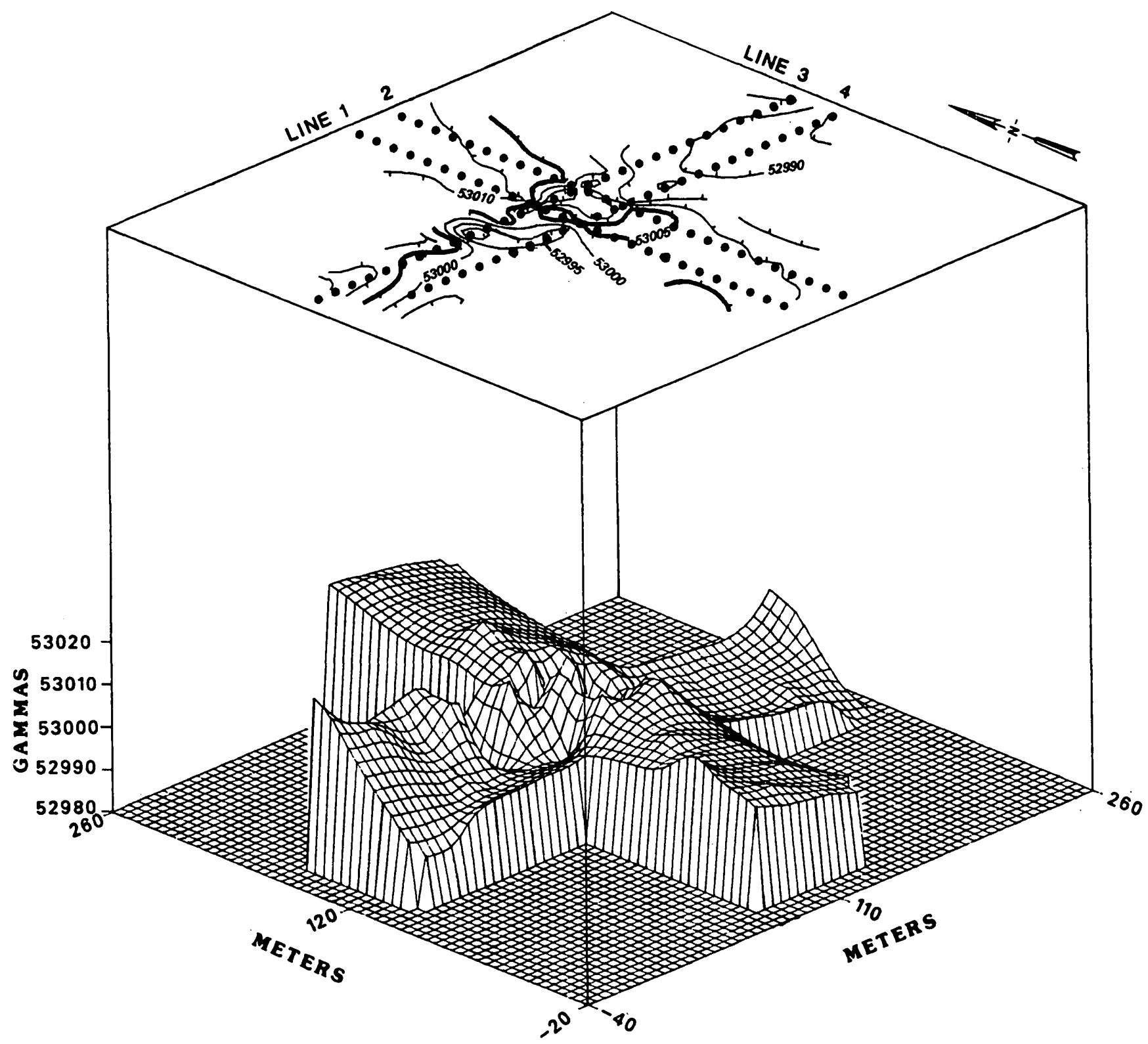

Figure 24. Three-dimensional model and contour plot of ground magnetometer data shown in figure 23 for feature 569 . Note the two areas of anomalously high values and two areas of anomalously low values associated with the collapse. 


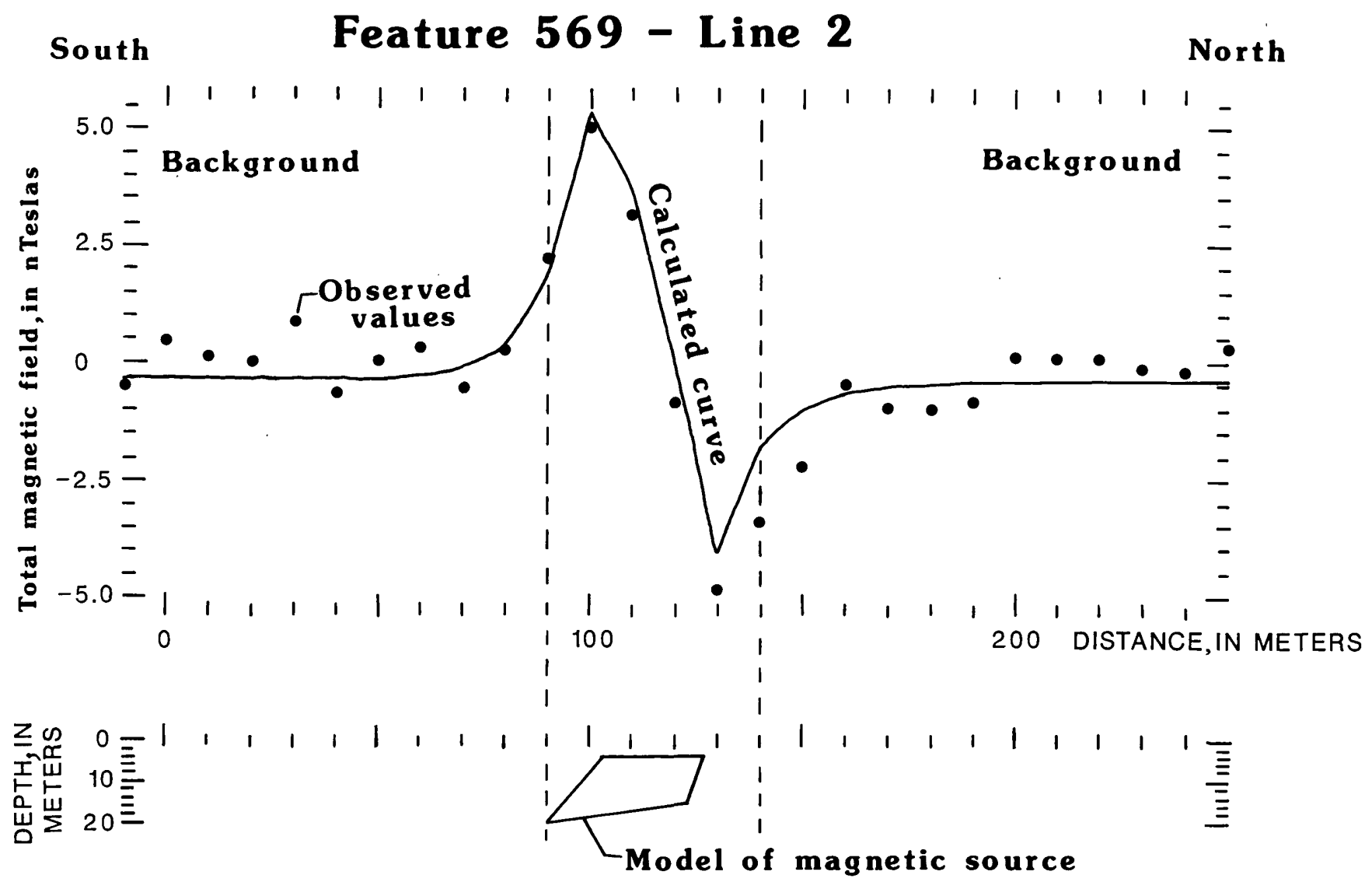

Figure 25. Computer modeling for the source of the dipole magnetic anomaly recorded along line 2 at feature 569 (fig. 23). The model shown produced the calculated curve which best fit the observed data. The magnetic susceptibility used for the body was $0.001 \mathrm{emu} / \mathrm{cm}^{3}$. Alternate models showed less fit between the curve and data but indicated that the source may continue to at least 50-m depth. 


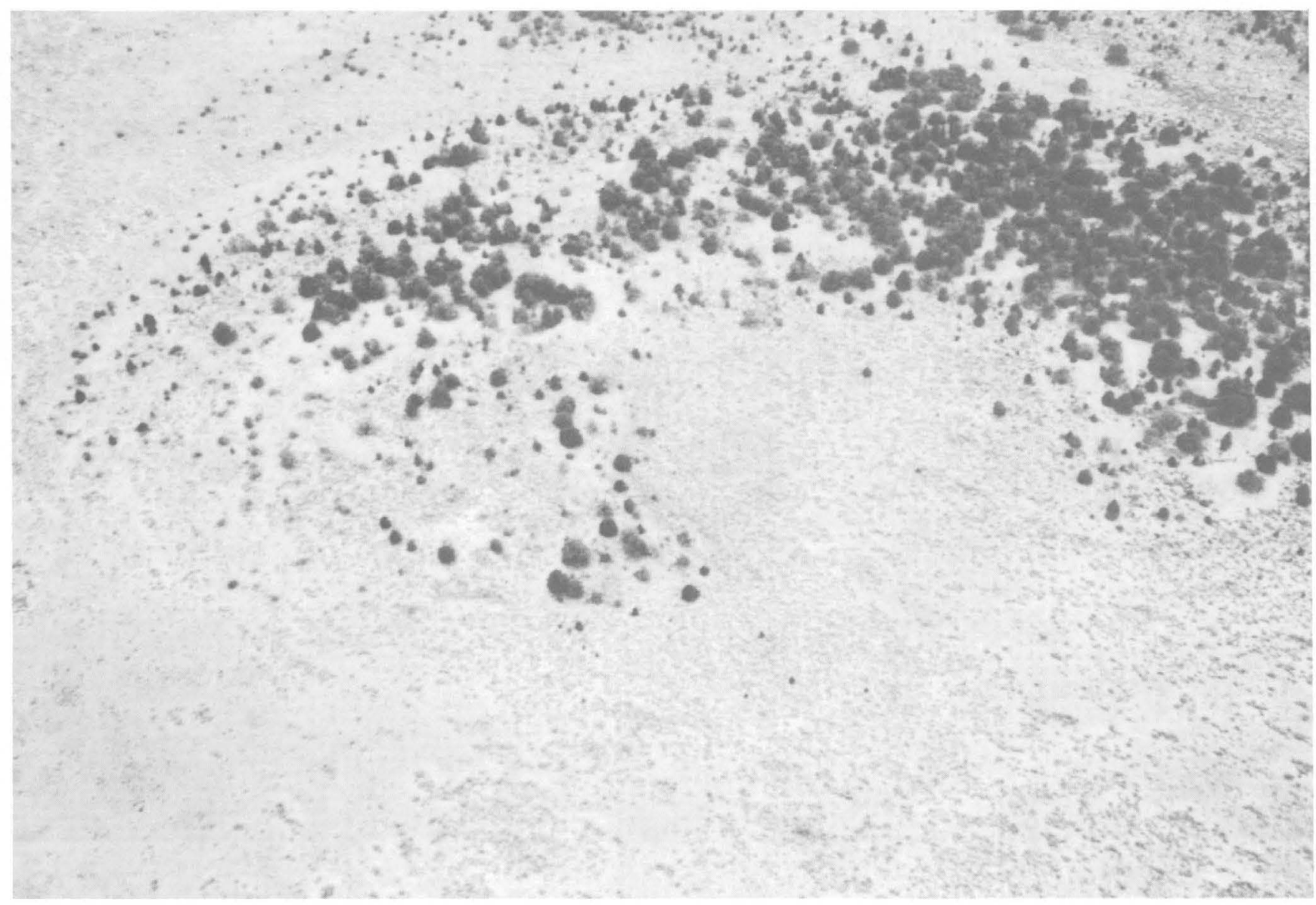

Figure 26. Feature 570 is a circular collapse about three-fourths enclosed by a raised rim of rocks of the Harrisburg Gypsiferous Member. The surface morphology of this collapse is similar to that of pipe 562 described earlier. Interior of collapse is about $140 \mathrm{~m}$ in diameter. View is to the west. 


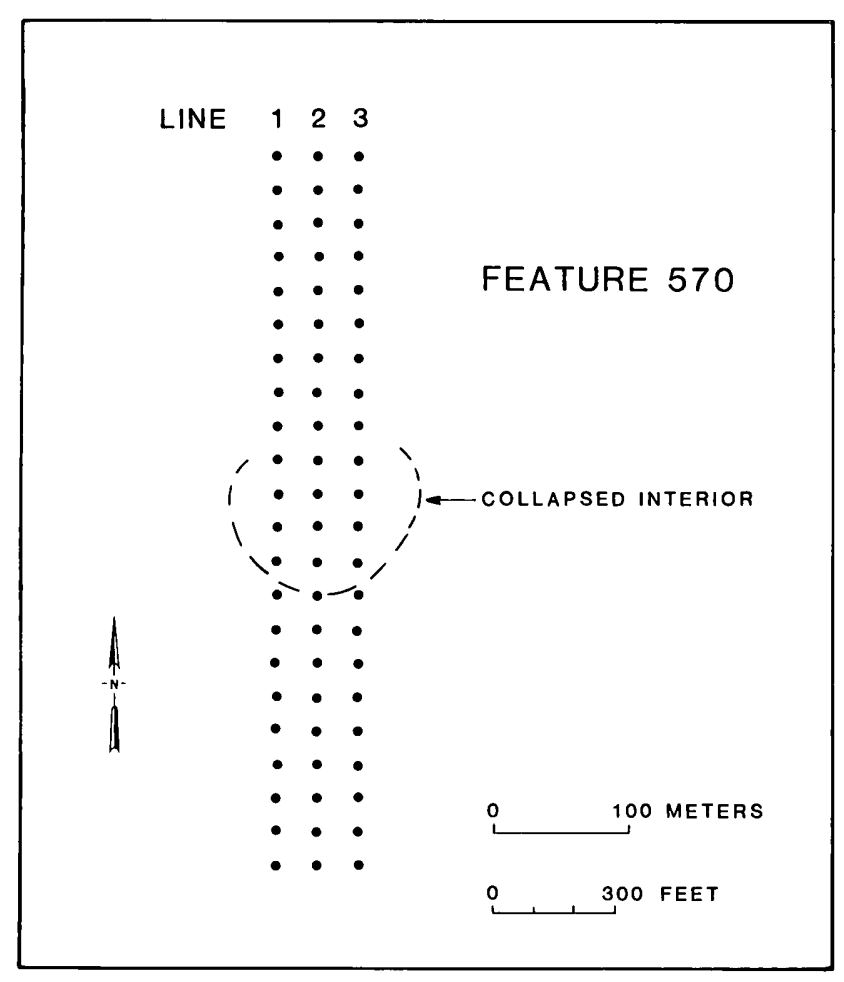

Figure 27. Map showing the location of ground magnetometer readings at feature 570 . The dashed line represents the inside base of the surrounding rim. The rim area (not shown) is about $50 \mathrm{~m}$ wide.

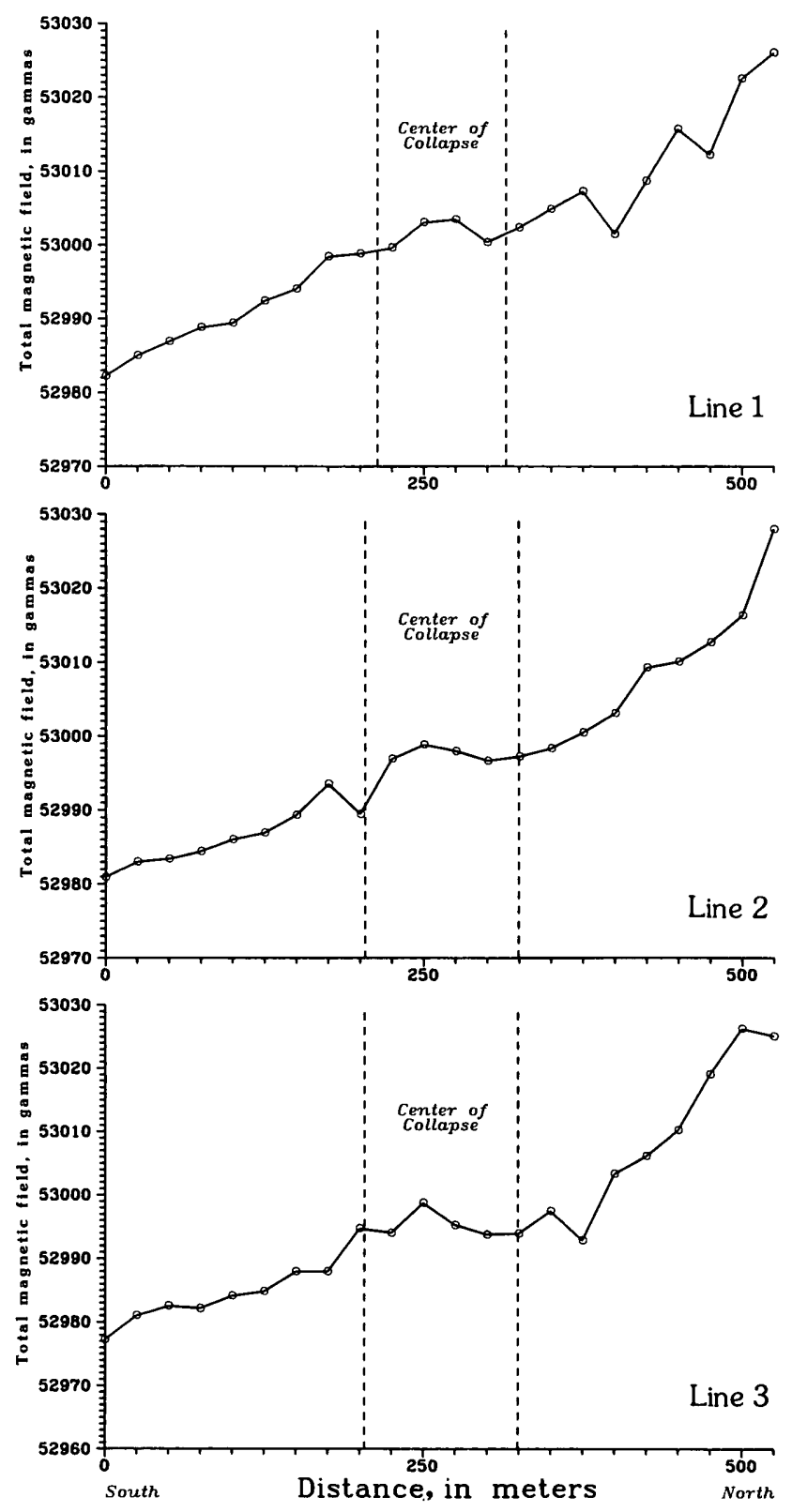

Figure 28. Total magnetic field profiles of ground magnetometer traverses at feature 570. Lines 1-3 are indexed to figure 27 . This magnetic data is the least variable data of all the features surveyed. Note the local magnetic gradient recorded in every line. 


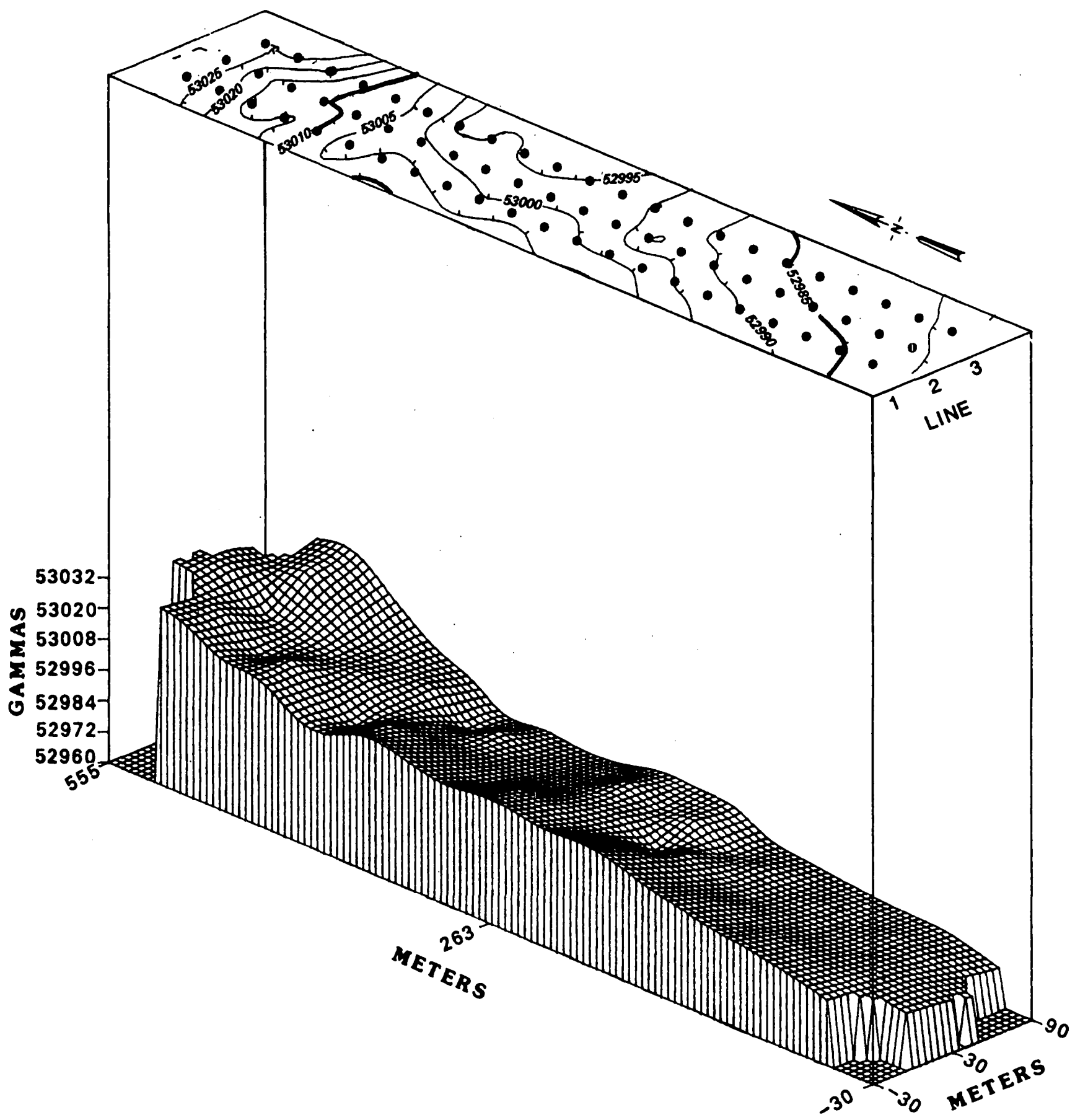

Figure 29. Three-dimensional model and contour plot of ground magnetometer data shown in figure 28 for feature 570 . The data show a local magnetic gradient but lack the magnetic anomalies associated with the other collapses surveyed. 


\section{Perlodragl}

Earthqualses \& Volcamoes (issued bimonthly).

Prèlminary Determination of Epicemters (issued monthly).

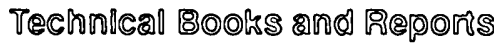

Professlomal Papers are mainly comprehensive scientific reports of wide and lasting interest and importance to professional scientists and engineers. Included are reports on the results of resource studies and of topographic, hydrologic, and geologic investigations. They also include collections of related papers addressing different aspects of a single scientific topic.

Bulletims contain significant dat\& and interpretations that are of lasting scientific interest but are generally more limited in scope or geographic coverage than Professional Papers. They include the results of resource studies and of geologic and topographic investigations; as well as collections of shor papers related to a sporific topic.

Water-Supply Papers are comprehensive reports that present significant interpretive results of hydrologic investigations of wide interest to professional geologists, hydrologists, and engineers. The series covers investigations in all phases of hydrology, including hydrogeology, availability of water, quality of water, and use of water.

Clrculders present administrative information or important scientific information of wide popular interest in a format designed for distribution at no cost to the public. Information is usually of short-term interest.

Water-Resounces Investog\&itlons Reports are papers of an interpretive nature made available to the public outside the formal USGS publications series. Copies are reproduced on request unlike formal USGS publications, and they are also available for public inspection at depositories indicated in USGS catalogs.

Opem-Fille Reports include unpublished manuscript reports, maps, and other material that are made available for public consultation at depositories. They are a nonpermanent form of publication that may be cited in other publications as sources of information.

\section{andps}

Geologlc $\mathbb{Q}$ undromgle M\&ps are multicolor geologic maps on topographic bases in $71 / 2$ - or 15-minute quadrangle formats (scales mainly 1:24,000 or 1:62,500) showing bedrock, surficial, or engineering geology. Maps generally include brief terts; some maps include structure and columnar sections only.

Geophnsical Imvestig\&teloms Mips are on topographic or planimetric bases at various scales; they show results of surveys using geophysical techniques, such as grovity, magnetic, seismic, or radioactivity, which reflect subsurf ace structures that are of economic or geologic significance. Many maps include correlations with the geology.

Miscellameous Investigations Sertes Maps are on planimetric or topographic bases of regular and irregular areas at various scales; they present a wide variety of format and subject matter. The series also includes 7 1/2-minute quadrangle photogeologic maps on planimetric bases which show geology as interpreted from aerial photographs. Series also includes maps of Mars and the Moon.
Coøl Investigations Mlaps are geologic maps on topographic or planimetric bases at various scales showing bedrock or surficial geology, stratigraphy, and structural relations in certain coal-resource areas.

Oll and Gas Investigations Charts show stratigraphic information for certain oil and gas fields and other areas having petroleum potential.

Milscellameous Field Studies Maps are multicolor or black-andwhite maps on topographic or planimetric bases on quadrangle or irregular areas at various scales. Pre-1971 maps show bedrock geology in relation to specific mining or mineral-deposit problems; post-1971 maps are primarily black-and-white maps on various subjects such as environmental studies or wildemess mineral investigations.

IHyolrologic Investignations Atllses are multicolored or black-andwhite maps on topographic or planimetric bases presenting a wide range of geohydrologic data of both regular and irregular areas; principal scale is $1: 24,000$ and regional studies are at $1: 250,000$ scale or smaller.

\section{Caralogs}

Permanent catalogs, as well as some others, giving comprehensive listings of U.S. Geological Survey publications are available under the conditions indicated below from the U.S. Geological Survey, Books and Open-File Reports Section, Federal Center, Box 25425, Denver, CO 80225. (Soe latest Price and Availability List.)

"Iublicartoms of the Geological Survey, 1879-1961" may be purchased by mail and over the counter in paperback book form and as a set of microfiche.

"Publicetions of the Geological Survey, 1962- 1970" may be purchased by mail and over the counter in paperback book form and as a set of microfiche.

"Publicatlons of the U.S. Geological Survey, 1971- 1981 " may be purchased by mail and over the counter in paperback book form (two volumes, publications listing and inder) and as a set of microfiche.

Supplements for 1982, 1983, 1984, 1985, 1986, and for subsequent years since the last permanent catalog may be purchased by mail and over the counter in paperback book form.

State corslogs "List of U.S. Geological Survey Geologic and Water-Supply Reports and Maps For (State)," may be purchased by mail and over the counter in paperback booklet form only

"Price amol Avallabinity List of U.S. Geological Survey Publicaatoms ${ }^{\circ}$ issued annually, is available free of charge in paperback booklet form only.

Selected coples of momilnty cotsilog "New Publications of the U.S. Geological Survey" available free of charge by mail or may be obtained over the counter in paperback booklet form only. Thnse wishing a free subscription to the monthly catalog "New Publications of the U.S. Geological Survey" should write to the U.S. Geological Survey, 582 National Center, Reston, VA 22092.

Nore.--Prices of Government publications listed in older catalogs, announcements, and publications may be incorrect. Therefore, the prices charged may differ from the prices in catalogs, announcements, and publications. 